NBER WORKING PAPER SERIES

\title{
THE EVOLUTION OF CONCENTRATED OWNERSHIP IN INDIA BROAD PATTERNS AND A HISTORY OF THE INDIAN SOFTWARE INDUSTRY
}

\author{
Tarun Khanna \\ Krishna Palepu \\ Working Paper 10613 \\ http://www.nber.org/papers/w10613
NATIONAL BUREAU OF ECONOMIC RESEARCH
1050 Massachusetts Avenue
Cambridge, MA 02138
June 2004

The views expressed herein are those of the author(s) and not necessarily those of the National Bureau of Economic Research.

(C2004 by Tarun Khanna and Krishna Palepu All rights reserved. Short sections of text, not to exceed two paragraphs, may be quoted without explicit permission provided that full credit, including $(C$ notice, is given to the source. 
The Evolution of Concentrated Ownership in India Broad Patterns and a History of the Indian Software Industry

Tarun Khanna and Krishna Palepu

NBER Working Paper No. 10613

June 2004

JEL No. G34, N85, O53

\section{$\underline{\text { ABSTRACT }}$}

As in many countries (Canada, France, Germany, Japan, Italy, Sweden), concentrated ownership was a ubiquitous feature of the Indian private sector over the past seven decades. Yet, unlike in most countries, the identity of the primary families responsible for the concentrated ownership changes dramatically over time. The resulting turnover is perhaps even more than turnover in leading U.S. firms over the same time period. It does not appear that concentrated ownership in India is entirely associated with the ills that the literature has recently ascribed to it in emerging markets. If the concentrated owners are not exclusively, or even primarily, engaged in rent-seeking and entry-deterring behavior, concentrated ownership may not be inimical to competition. Indeed, as a response to competition, we argue that at least some Indian families have consistently tried to leverage internal markets for capital and talent inherent in business group structures to launch new ventures in environments where external factor markets are deficient. In the process they have either failed hence the turnover in identity or reinvented themselves. Thus concentrated ownership is a result, rather than a cause, of inefficiencies in markets.

Even in the low capital-intensity, relatively unregulated setting of the Indian software industry, we find that concentrated ownership persists in a privately successful and socially useful way. Since this setting is the least hospitable to the existence of concentrated ownership, we interpret our findings as a lower bound on the persistence of concentrated ownership in the economy at large.

Tarun Khanna

Harvard Business School

tkhanna@hbs.edu

Krishna Palepu

Harvard Business School

kpalepu@hbs.edu 


\section{The Evolution of Concentrated Ownership in India Broad Patterns and a History of the Indian Software Industry ${ }^{1}$ \\ Tarun Khanna and Krishna G. Palepu \\ June 30, 2004}

\section{Introduction}

Concentrated ownership has been an important feature of the Indian private sector for the past seven decades. In this respect, India is no different from several other countries, including Canada, France, Germany, Japan, Italy, and Sweden. However, we show that, unlike in these countries, the identity of the primary families responsible for the concentrated ownership changes dramatically over time. In fact, by some measures the changes are even more dramatic than in a comparable set of U.S. data.

Concentrated ownership exists at any point in time because of institutional voids, the absence of specialized intermediaries in capital markets (Khanna and Palepu 1997, 2000a). However if these concentrated owners are not exclusively, or even primarily, engaged in rent-seeking and entry-deterring behavior, there is no intrinsic reason why concentrated ownership is inimical to competition. Indeed, as a response to competition, we argue that at least some Indian families - the concentrated owners in question - have consistently tried to use their business group structures to launch new ventures. In the process they have either failed - hence the turnover in identity - or reinvented themselves.

Further, family-owned business groups, typically diversified over several industries, can co-exist with specialist firms focused on a particular industry. We demonstrate this through an examination of the history of India's globally competitive software industry. This is an intriguing setting in which to explore the role of concentrated ownership since it is the setting least hospitable to the advantages that groups might have. We argue that groups' generally advantageous access to capital and

\footnotetext{
${ }^{1}$ We are grateful to Randall Morck for coordinating and spearheading the project on the History of Concentrated Ownership at the National Bureau of Economic Research, to Dr. Gita Piramal (Mumbai, India) for access to some of her historical data on Indian business families, and to seminar audiences who commented on earlier drafts of this paper in Cambridge and Fontainebleu. The Division of Research at the Harvard Business School financed this work. All errors remain our own.
} 
talent through internal markets - when external markets do not work as well - offers less of an advantage, if any, in this setting. Here groups are also least able to influence regulations, since the sector is one of the few left untouched by vestiges of India's famed regulatory miasma, the License Raj. Yet it turns out that concentrated ownership, in the guise of business groups, plays a defining and prominent role even in this inhospitable setting, and does so in a way that is not inimical to entry from de novo entrepreneurs. We interpret the privately successful and socially useful persistence of groups in the software industry as a lower bound on the persistence of concentrated ownership in the economy writ large.

The rest of the paper is organized as follows. Section II begins with a sweeping overview of dominant business groups in India over the past century. We show that, while particular families have acted as concentrated owners at each of three points in time in the past seven decades, the identity of these families has changed drastically over this time period. We then consider two, not mutually exclusive, explanations for the persistence of concentrated ownership. The first (Section III) is political relationships between dominant families and the power structure. The second (Section IV) is a process of entrepreneurship by the dominant families. From these sections we conclude that it is difficult to tell a story of concentrated ownership resulting purely in stasis and rentseeking. Section V characterizes changes in India during the last decade as moving towards less regulation and government intervention and toward freer markets. Even in this setting, we point out that family-based business groups continue to thrive. Finally, in Section VI, we study the software industry.

\section{A Brief History of Corporate Ownership in India}

While there has been organized economic activity in India for hundreds of years, it was relatively fragmented till the advent of the British Raj. Under the Mughals, from approximately $1100 \mathrm{AD}$ to $1650 \mathrm{AD}$, there was only a semblance of a 'national market.' The Mughals were content with tax revenues and tributes that they received as a result of their power and therefore did not rely on the merchant classes. The fragmentation and demise of the Mughal empire marked the advent and co-existence of dozens of smaller 
principalities, each of whom came to rely on local merchants and local financiers to sustain their princely states. Thus were created the nuclei of several prominent family businesses.

The British empire gradually filled the void left by the Mughals. And British merchants set up trading businesses in India after the East India Company lost its monopoly on trade with India, giving rise to the creation of several large trading houses.

Table 1 offers a birds-eye view of the different factors underlying the emergence of family based business groups over the past century. We list representative business groups that arose in each of four different time periods (though the Tata and Birla groups predate 1900), as well as a generic factor that described the rise of that type of group at that time.

By the early 1900s, in addition to the British trading houses, a number of indigenous business groups had come into prominence. Whether this happened in an atmosphere inimical to the rise of indigenous enterprise (Swamy, 1979), indifferent to it (Das, 2000, Chapter 5), or supportive of it (Ferguson, 2002) is a matter of continuing controversy.

Subsequently, the Indian economy underwent several phases of major structural changes after India achieved independence from Britain in 1947. In the first phase, in the 1950s, the assets controlled by the British trading houses were transferred to Indian owners. In the second phase, from the late 1950s through the 1970s, the Indian government intervened in the economy through a variety of measures, which collectively came to be known as the "Licence Raj." Finally, there was an economic reform era, which began with small steps of deregulation in the 1980s, and picked up speed in the 1990s following a major economic crisis in 1991.

The next two subsections show that concentrated ownership persisted in India over several decades but that the identity of the concentrated owners changed over time quite drastically.

\section{The Persistence of Concentrated Ownership}

Remarkably, while the economy was governed by these significantly different regimes over time, family business groups continued to dominate the Indian corporate 
landscape. Table 2 shows comparative statistics on the Indian state owned companies (SOEs) (or public sector companies) and exchange listed private sector companies, and multinational companies (MNCs) operating in India, as of $1993 .{ }^{2}$ The ratio of number of traded private sector companies to state owned companies was approximately 17 to 1 . Thus, there were far more traded private sector companies than public sector companies. However, public sector companies were on average significantly larger than traded private sector companies. Revenues of all traded private sector companies was only 1.5 times the revenues of state owned companies; similarly, assets of traded private sector companies were only 1.2 times the assets held by the public sector companies. More strikingly, the total amount of equity capital in traded private sector companies was only 0.51 times the equity in public sector companies. Thus, private sector companies, while large in number, were more fragmented and relied on far less equity investment, relative to the public sector companies.

Table 2 also compares the traded Indian private sector companies with multinational companies operating in India as of 1993. For each MNC operating in India, there were approximately 17 exchange listed private sector companies. Domestic private companies we 4.3 times larger than MNCs in sales, and 9 times in terms of assets, 6.7 times in terms of equity. Thus MNCs played a relatively minor role in the Indian corporate sector as of 1993.

Within the indigenous private sector, a distinction should be drawn between group-affiliated companies and unaffiliated companies. The term group deserves discussion. Hazari (1966) in a classic study of Indian business groups, defined a group as the 'area over which a decision-making authority holds sway' (1966: page 7). The decision-making authority in question was almost always a family, though it could be a close-knit ethnic community as well. The area of control in effect was almost always a very diversified range of businesses. He started his work by saying that it was 'based on the proposition that the business group, not the individual joint stock company, is the unit of decision and, therefore, of economic power.' (1966: preface). Earlier work concurred. For example, another influential study opined that the study of concentration of economy power is 'unreal if divorced from a study of communities' (Gadgil, 1951, p 29; the

\footnotetext{
${ }^{2}$ Date drawn from Khanna (1997).
} 
reference is to ethnic communities). ${ }^{3}$ Hazari's study provided an influential evaluation of the extent to which business groups had exercised monopoly power (he concluded that they had). Subsequent regulators and policymakers (e.g. Dutt, 1969) built on this work to demonstrate that the control that Hazari used as the defining feature of groups was often exercised through non-equity channels, e.g. through family ties or through manipulation of the boards of directors.

In 1993, there were a total of 1113 group companies that were publicly listed on one of India's several stock exchanges. Post-independent India also gave birth to a large number of new companies that went on to become publicly listed on the countries' stock exchanges. In 1993, there were 1539 publicly listed non-group companies. These companies were in part a result of government's policy of restricting existing companies from expanding capacity. Promoters of these companies were also able to launch these businesses with relatively small amount of own equity, thanks to the access to capital from state-owned financial institutions, and public capital markets.

Table 3 compares group and non-group companies listed on Bombay stock exchange (BSE) as of 1993. ${ }^{4}$ The sample consists of 567 group firms and 437 non-group firms for which the necessary data was available. The group affiliates are members of 252 different groups. Ninety five percent of the groups have five or fewer affiliates traded on the BSE and the largest group (the Tata group) has twenty one affiliated companies traded on the BSE. The mean (median) sales of group affilates is 1,411 (666) million Indian rupees. This is significantly larger than the mean (median) sales of unaffiliated firms, which is 366 (217) million rupees. The mean (median) age of group firms, which is 28.3 (22) years, is also significantly larger than mean (median) age of unaffiliated firms. The mean (median) Tobin's q for group firms was 1.39 (1.14), insignificantly different from the mean (median) value of 1.37 (1.06) for the non-group firms.

\footnotetext{
${ }^{3}$ In recent work, Khanna and Rivkin (2002) have demonstrated econometrically that business groups in Chile can, at best, be identified only partially on the basis of equity interlocks. Director ties and common owner ties play an important role in delineating what Chileans (regulators and participants in financial markets) deem to meaningfully be part of a business group. Thus control is exercised, de facto, in ways very similar to India.

${ }^{4}$ These data are from Khanna and Palepu (2000)
} 
The total sample has the following mean (median) ownership structure: foreign institutions, 8.9 (1.6) percent; domestic institutions, 13.9 (10.2) percent; insiders 27.1 percent (26.5 percent); directors, 9.4 percent (3.4 percent); top fifty owners excluding the above categories, 6.21 (4.0) percent. The remainder is held by dispersed shareholders. Relative to unaffiliated firms, group firms, on average, have significantly higher percentages of foreign and domestic institutional ownership, and higher insider ownership.

In summary, the Indian corporate sector as of early 1990s had the following profile: A little more than a hundred relatively large state owned enterprises and more than 2500 smaller publicly traded private sector companies, roughly equally split between group affiliated and non-group companies. In the private sector, companies affiliated with business groups, with concentrated family ownership, accounted for a substantial proportion of assets.

\section{The Lack of Persistence of the Identity of Concentrated Owners}

While there has been a significant persistence in the phenomenon of concentrated family ownership in India over much of the $20^{\text {th }}$ century, there was less persistence in the actual composition of the top business groups themselves. The Tata group remained the largest Indian group during the entire 60 year period on which we present data below. But other leading groups from the pre-Independence era (e.g. British groups such as Martin Burn, Andrew Yule, Inchcape) did not persist in their then-form. Several new business houses rose to prominence during this period, including the Thapar group in the 1950s and 1960s, the Ambani group in the 1970s and 1980s, and the Wipro and Munjal groups in the 1980s and 19990s. Thus, the history of modern Indian corporate sector is characterized by both a persistence of concentrated ownership at the aggregate level, and a significant lack of persistence of dominance at the individual business group level.

To demonstrate this more formally, we analyzed the persistence of dominance for Indian business groups over the past 60 years. This is based on size rankings (assets) for the fifty largest business groups compiled by Dr. Gita Piramal of Mumbai, India, for the years 1939, 1969, and 1999 (Table 4). Her rankings have themselves been compiled from miscellaneous historical sources, including, but not limited to, various government 
reports commissioned by the Government of India at various points in time. Note that the rankings are not of firms, but of groups. That is, all firms controlled by a single entity, typically a family, are treated as a single economic unit. As a benchmark against which to compare our analysis of the persistence of Indian groups, we also amass market valuebased rankings of the 50 largest U.S. firms at identical time periods. These data are compiled from Compustat and are in Table 5.

Consult Table 4 for some summary statistics. Our first observation is that the Indian data show considerable turnover in ranks. 32 out of 50 of the top groups in 1969 were not in the top 50 list in 1939. 43 of the top groups in 1999 were not in the top 50 list in 1969. This flux in the list of largest entities is greater than that in the U.S. in comparable time periods where 28 and 37 firms enter the top 50 U.S. list in 1969 and 1999 respectively. The comparison is all the more dramatic because the Indian data measures groups, which are collections of firms, while the U.S. data measures firms. (In other words, individual firms within Indian groups almost certainly would have greater turnover than that suggested by the data on groups.)

Of the 18 groups that remain in the top 50 list in the $1939-1969$ period (50 less 32), 16 change ranks while only 2 have ranks that remain unchanged. Further, 10 of the 18 groups whose ranks change do so dramatically (that is, by more than 10 ranks in either direction). In contrast, a smaller proportion of the firms whose ranks change in the U.S. top-50 list in 1939-1969 do so dramatically (5 out of 22). The proportion of radical rank changers is also higher in India during the 1969-1999 period (3 out of 7) than in the U.S. in the same period (5 out of 13).

Note also that the turnover in the ranks of Indian groups is greater in the second 30 -year window than in the first. This is important because part of the turnover in the 1939-1969 period was due to transfer of assets from British ownership to Indian ownership at the end of the British colonial rule of India. The turnover in the 1969-1999 period reflects less unusual circumstances.

Finally, an analysis of the groups or firms that are born in any period suggests that they do not generally leapfrog to the top of the rankings, nor do the top groups or firms in any period dramatically fall off the rankings. A regression of ranks on 'births' and on a variable that measures whether the group or firm is going to 'die' (that is, exit the top 
rankings) the following period reveals positive and significant coefficients on both variables. That is, firms born in a particular period have higher ranks (are smaller) and firms that are about to die in the next period have higher ranks (are smaller). The regression reveals point estimates that are quite similar for both the Indian top50 group and U.S. top50 firm rankings, hinting at some underlying similarity in the competitive processes underlying such turnover.

The above pattern of corporate ownership in India is inconsistent with a pure corporate ownership entrenchment story. We will turn, in each of the next two sections, to considering two potential explanations for concentrated ownership in an emerging economy like India (Ghemawat and Khanna, 1998; Khanna, 2000). The first explanation has to do with rent-seeking behavior by prominent business families with strong political connections. Under this hypothesis, business families control business groups to extract personal gains, and attain their position through directly unproductive economic activities and through their influence over government policies and actions. The second hypothesis is that family business groups arise as a result of their entrepreneurial activity which is in short supply in emerging economies such as India with significant market failures and institutional voids (Khanna and Palepu, 1997, 1999, 2000a,b).

\section{Political Connections and Rent Seeking Behavior}

In this section, we first describe how business government relationships evolved over the relevant timeframe for this paper, and then consider particular groups' relationships with the government, with a view to uncovering whether or not there is systematic evidence to support the political connections story for persistence of concentrated ownership.

\section{Shifting Contours of Business Government Relations}

A close relationship between business and government had existed for quite some time in India. During the British colonial rule, the interest of British companies was naturally favored over the interest of Indian business houses (Piramal, 1998; pp. 162, 230). As the movement for freedom from the British Raj gathered momentum in the 
1920s and 1930s, close relationships developed between Indian businesses and leaders of the political movement for India's independence. Underscoring their symbiotic relationship in a letter, as he was building steam for India's independence movement in 1927, Mohandas Gandhi told G.D. Birla, a prominent Indian businessman, "I am ever hungry for money" (Cited in Piramal, 1991).

The pragmatic collaboration between the new Indian government and the business community to build modern India continued in the immediate aftermath of independence (1947 to 1960). For example, Hindalco and Telco collaborated with the Government of India to set up Hindustan Aeronautics Limited to develop the aviation sector in India. However, the relationship soured in the 1960s as Indian government, under the leadership of Prime Minister Jawarharlal Nehru, moved the country's economic policies towards socialism. This period, often characterized as the License Raj, began with the government's desire to curb big business houses, and to directly intervene in economic activities through public sector corporations.

Several prominent government commissions, including the Mahalanobis Committee of 1964, Monopolies Inquiry Commission of 1965, R. K. Hazari Committee of 1966, and the Industrial Licensing Policy Committee of 1969, were established during this period. These commissions documented evidence that big business houses were exerting significant influence on Indian economy, and that they were exploiting growth opportunities through favorable access to finance and government permits. These commissions were followed by the creation of Monopolies and Restrictive Trade Practices Act (MRTP) and the Foreign Exchange Regulation Act (FERA), and the nationalization of the largest private sector banks. These policy changes, spearheaded by the government of Prime Minister Indira Gandhi, imposed strict government controls on private sector's ability to pursue growth opportunities, access domestic finance, or collaborate with foreign technology or business partners. The FERA act also required that multinational companies operating in India divest their ownership so that a majority of the ownership in the Indian operations was held by Indian shareholders.

In the mid-1980s, under the government of Prime Minister Rajiv Gandhi, a gradual move towards deregulation began. These reforms relaxed some of the MRTP and import restrictions, and freed up some of the economy from licensing requirements. 
Despite these changes, the Indian economy grew at a fairly modest rate during this entire period, culminating in a foreign exchange payment crisis in the early 1990s. This crisis led to a dramatic deregulation and liberalization of the Indian economy. Under the Congress Party government of Prime Minister Narasimha Rao, and then subsequently under the BJP government of Prime Minister Atal Behari Vajpayee, the MRTP and FERA Acts were repealed, several sectors of the economy including telecom, commercial aviation, and banking - previously reserved for the public sector - were opened to private sector, and import duties were dramatically reduced.

\section{Business Groups and Government}

As the contours of business-government relations shifted in India during the past half century, there were complex shifts in relationships between individual business groups and the government in power. Different groups occupied different positions of favoritism at different times. There is evidence that these political connections played an important role in the rise and fall of different business houses. But it is interesting that the groups that remained dominant throughout did so despite ebbs and flows in their relationship with the government. Clearly proximity to government was not the only cause of their success.

Consider the House of Tata. JRD Tata, in the pre-independence period, presided over a group that was, in fact, quite reliant on government contracts. Before World War I, Tata Steel would not have started without a guarantee from the British government for Indian Railways, nor would Tata Steel have grown to the largest integrated steel factory in the British Commonwealth without such government contracts. And Tata Steel was protected by tariffs against German and Japanese, if not British, steel (Hazari, 1986). The Tatas adopted a neutral stance in the Independence movement. As Piramal (1998; p. 481) puts it, in the British Raj, the Tata Group 'bristled' with knights.

But by 1960, the group remained India's largest even though it had fallen out of favor, as it was opposed to the socialist philosophy of Prime Minister Nehru. Reacting to the various government commissions suggesting that large business houses manipulated and abused the licensing system, JRD Tata is reported to have cynically said, "Yesterday in Parliament, they called me a monopolist with 'great concentration of power.' I wake 
up every morning and I am supposed to say, 'I have great concentration of power. Whom shall I crush today? A competitor or a worker in my factory or the consumer?' .... No dear boy I am powerless .. I cannot decide how much to borrow, what shares to issue, at what price, what wages or bonus to pay, and what dividend to give. I even need the government's permission for the salary I pay to a senior executive" (quoted in Das, 2000; pp 168-169). Indeed, far from manipulating the licensing system to its advantage, the Tata group reportedly made 119 new proposals for expansions in (existing or de novo) businesses between 1960 and 1989 and every one of them was rejected (Das, 2000; p. 93). Further, some of the Tata's assets were nationalized, most famously Tata's airline. And JRD Tata contributed to the Swatantara Party's coffers, to create an alternative to Nehru's Congress since the former stood for less regulation than that espoused by the latter.

Turn to the Birla's next. Under G.D. Birla, the group supported the Independence movement financially. Sarojini Naidu, herself a prominent figure in the India of that era, famously said 'it took all Birla's millions to enable Gandhi to live in poverty. And he gave for free' (Piramal, 1998). The group rose to prominence in the post-independence period, and by 1969 became the second largest Indian business group. However, under the government of Prime Minister Indira Gandhi, the Birla group became the target of criticism for its manipulation of the licensing system, as it was targeted by the Hazari reports and criticized for preempting licenses - that is, for applying for licenses which it then failed to use. Indeed G. D. Birla's successor, Aditya Birla, was allegedly sufficiently disappointed by being, in his view, unfairly tarnished by the government's allegations, that he simply shifted his expansion plans overseas. So much so that, between 1970 and 1995, the Birla's had established plants in Egypt, Indonesia, Malaysia, the Philippines, and Thailand, with overseas activity accounting for a third of their overall business, and the world's leading position in viscose staple fiber, palm oil and insulators, and the world's sixth largest position in the manufacture of carbon black (Das 2000, pp 176). The implication is that the size and prominence of the group is due to the Birla's entrepreneurial tendencies finding expression around the licensing restrictions at least in part, rather than by embracing them and engaging purely in rent-seeking activities. 
All this is not to deny that rent-seeking existed. Clearly there were abuses in the system, far too many indicators are consistent with this. See recently Bertrand, et al. (2002), for example, and our own earlier work (Khanna, 2000; Khanna and Palepu, $2000 \mathrm{c}$ ) on the dark side of business groups. ${ }^{5}$ But it is a mistake to tar the entire corporate sector with the same broad brush. As the caselets above suggest, some of the groups remained dominant despite sustained periods of falling out of favor. Others directed their energies to expansion outside India rather than manipulating the licensing system.

Further, note the following possibility of possibly misplaced emphasis and incorrect inference. We do not contest that the license raj was bad for economic development. As Hazari (1986; pp. xxiv) put it, 'the abuses and failures are no longer, as the Italians say, mere apertura; they are wide-open doors.' But whether concentrated ownership was the cause of this miasma is less clear. The 'Kafkaesque maze of controls' (Bhagwati, 1993) had more to do with a heady fascination with the intellectual cuisine of the London School of Economics and Cambridge (Hazari, 1986), and the wonder of the then ascendant Soviet planning machine, than with the actions of India's dominant family businesses. Business groups had to either manipulate it, as some did, or invent themselves around it, as did others.

\section{Entrepreneurship in the context of institutional voids}

In an emerging economy, many institutions necessary for the functioning of product markets, labor markets, and financial markets are typically missing or underdeveloped. In India, this was certainly true under colonial rule. Indeed, the heavy state intervention in the economy in the first few decades of independence was justified by successive governments as a way to deal with these market failures.

As Khanna and Palepu (1997, 1999, 2000a,b) and others (Leff, 1976, 1978, Strachan, 1976) argue, business groups could be seen as a private sector response to the institutional voids in the economy. Groups often perform functions traditionally performed by market institutions in more mature markets. One such important function

\footnotetext{
${ }^{5}$ De Long (2001) suggests, based on an analysis of growth rates of several countries, that the effects of the License Raj might have been overstated (or, at least, the negative effects were offset by other positive factors).
} 
is the provision of something akin to venture capital, consisting of identifying promising new business opportunities in the economy and exploiting them with in-house risk capital and managerial talent, which are traditionally in short-supply in the economy at large. This, in turn, leads to the observed predominance of the business group type of organizational form in emerging economies.

It is important to note that this hypothesis only implies that economies such as India will have a preponderance of business group type organizations. It does not necessarily imply that the same set of business groups will continue to be prominent in the economy over time. This continued success of a business group under this explanation depends on its ability to sustain its entrepreneurial nature over a long period of time. While some groups may succeed in this endeavor, others may fail. In this sense, the rise and fall of business groups over time in emerging economies is akin to the rise and fall of businesses in advanced economies.

The history of the Tata group provides a classic example of how some Indian business groups pursued new business opportunities successfully over time. Figure 1 shows the time line of the entry of the Tata group into various new businesses, from 1870 to 2001 - textiles in 1874, hospitality industry in 1902, steel in 1907, power in 1910, cement in 1912, soaps and toiletries in 1917, printing and publishing in 1931, aviation in 1932, chemicals in 1939, consumer electronics in 1940, commercial vehicles \& locomotives in 1945, cosmetics in 1952, air-conditioning in 1954, pharmaceuticals in 1958, tea and coffee in 1962, information technology in 1968 (see Section VI), watches, financial services in 1984, auto components in 1993, telecom services in 1994, passenger cars in 1998, retail in 1999, and insurance in 2001. Despite the remarkable diversity of these businesses, the group has been able to maintain a leading position in many, if not most, of the businesses it entered over time. It only had to exit a small handful of businesses in its history - aviation in 1953 (due to government nationalization), locomotives in 1970, soaps and toiletries in 1993, cosmetics and pharmaceuticals in 1998 , cement in 2000, textiles in 2001, and printing and publishing in $2003 .^{6}$

\footnotetext{
${ }^{6}$ There appears to have been a short-lived and aborted entry into shipping in the late 1890s. This effort, along with those of a number of other Indian entrepreneurs until the establishment of Walhand Hirachand's Scindia shipping company, foundered when faced with the British-controlled shipping 'conference' controlled by Inchcape and others.
} 
The role played by the Tata's is exactly to fill the institutional void of venture capital in these instances, as well as to provide an exit mechanism to aspiring entrepreneurs in the absence of well-functioning public markets. For example, Tata Chemicals supported its engineers' efforts to innovate. In some instances, these engineers left to start up their own companies, and the Tata's had been known to buy out the results of these efforts subsequently (see example in Piramal, 1998; p. 473).

It is interesting that this process of entrepreneurship is often criticized in the media as being undisciplined and characterized by a failure to adhere to core competencies. This reflects a mistaken notion of what constitutes the 'core competence' (Selznick) as it were. Here it is at least as much an ability to circumvent institutional voids as it is some industry-specific knowledge. As N. A. Soonawala, a board member of Tata Sons, the main holding company of the Tata's, said to us in 1998 in response to criticisms by leading multinational consulting firms at the time, "If everyone is told not to go into unrelated businesses, how will the airlines, oil, and telecommunications industries develop? The government has said that they can't do it. So there's a social benefit to all this diversification" (Khanna, Palepu, and $\mathrm{Wu}, 1998)$.

An important feature of entrepreneurship in India is the reliance on the ethnic group, to supplement family networks (Lamb 1976). The Marwari, Gujerati and Parsi communities are, by far, the dominant business communities in India in recent decades, and even today. For example, these communities collectively controlled 62 of the 100 largest companies in 1989 (Piramal, 1989). Other active communities include the Punjabis, Chettiars and the Maharashtrians.

These communities share their distinctive tenors. For example, Gujeratis were traditionally traders with countries in the Middle East and East Africa. Parsis, from the small minority Zoroastrian community in India, were most "Westernized" in their business outlook, and traditionally played the role of intermediaries with Europe. Marwaris, a demographically small segment originally from the state of Rajasthan in western India, have been the most geographically spread business community, pursuing businesses all over the country. By 2000, Das (p 174) quotes an estimate that says that the Marwaris controlled half the industrial assets of India. 
Tinberg (1978) chronicled the modus operandi of Marwari businesses.

Traditionally, the great Marwari firms had networks spreading all over Asia and deep into China. They relied on their own kin for information and for effective contractual enforcement. In our terminology, these ethnic networks were substitutes for institutional voids, and shared features with the networks used by the Genoese and Maghribi traders studied by Greif (1994) and by the Rothschilds. Famously, Marwaris'simple and rigorous, if manual, cost accounting systems provided a cost-effective means of financing that allowed them to stomach risks in a time of capital scarcity.

In pre-British and British India, the history of prominent business groups is characterized by the willingness of the successful members of each ethnic community to help spawn new members, some times even to compete with their existing businesses. For example, several prominent Marwari groups in existence today are spun off from the Birla group. Birlas have been known to actively encourage talented employees to pursue their own business opportunities, and sometimes even finance these new ventures. Several groups spun off the Birla group (e.g. Khaitan, Kejriwal, to cite just a couple) and continue to exist today (Piramal, 1998; p. 142-43). Kasturbhai Lalbhai, a prominent textile businessman, helped his ethnic group members with the technology of setting up textile mills. Walchand Hirachand Doshi actively promoted shipping companies, including direct competitors of his own, as part of the struggle against the British Raj (Piramal, 1998; p. 162, 230). As Lamb puts it (1976), the acts of entrepreneurship in British India were heroic, especially in view of the powerful interests arrayed against the entrepreneurs.

The entrepreneurship has continued in modern times and extends beyond expansion of product lines to institutional innovation. A good example is that of the Ambanis. A relatively recent entrant into the leading business groups, the flagship company, Reliance, is India's only entry into the Global Fortune 500. While many point to a close relationship with the government of Mrs. Indira Gandhi as being part of the reason for the company's initial success - founder Dhirubhai Ambani famously said he would 'salaam' (salute) anyone to sell his ideas ${ }^{7}$ - the fact remains that the group has developed world-class capabilities in managing large-scale capital intensive projects, and

\footnotetext{
${ }^{7}$ India Today, June 30, 1985. Cited in Piramal (1991).
} 
is an innovative financier. Its most notable contribution to institutional innovation in India is perhaps the creation of an equity cult. As Das (2000, chapter 13) chronicles, Dhirubhai Ambani single-handedly mobilized small investors around the country in 1977 and listed on the Bombay and Ahmedabad stock exchanges when the dominant public financial institutions would not lend him capital. Between 1980 and 1985, the number of Indian shareholders went from 1 to 4 million, and fully $25 \%$ of these shareholders owned shares in Reliance, the Ambani company.

To recapitulate, we have considered two classes of explanations - rent seeking behavior and entrepreneurial activity - to explain the dual phenomena of persistence of concentrated ownership, but turnover in the identity of the concentrated owners. Both explanations have circumstantial evidence in favor of them. Superficial attempts to attribute data to one or the other of these explanations should be met with disdain. It is hard to believe, in particular, that rent-seeking can provide a full explanation, especially of the shifting identity of concentrated ownership.

\section{The recent evolution of groups and markets}

The evidence presented above is consistent with the idea that Indian business groups with family and community ties arose historically, in part, due to the absence of well-developed financial markets. During the past three decades, financial markets in India have developed significantly, in part due to paradoxical consequences of policies aimed at other ends during the era of socialism, and in part due to direct attempts by the government aimed at market development during the more recent reform era.

Under the Foreign Exchange Regulation Act passed during the socialist era of the 1960s and 1970s, multinationals operating in India were required to reduce their ownership to below $40 \%$, and divest the rest to Indian investors. To comply with this requirement, many multinationals offered their shares to public investors through public offerings on the Bombay Stock Exchange. The issue prices were set by the Controller of Capital Issues, a government body, at book values which were often dramatically below economic values. As a result, individual investors were able to buy shares at very attractive prices in very good companies. These public offerings had a number of 
spillover effects. First, they created a culture of equity ownership in India on a large scale, because many retail investors were attracted to the opportunity of earning significant returns that were almost assured. Second, the process of listing these companies on Bombay stock exchange resulted in the creation of an intermediation and market infrastructure - accounting and auditing professionals, financial analysts, investment bankers, and stock-brokers.

When India began to liberalize its economy in the 1990s, one of the key objectives of the government policy was to attract foreign institutional investors. To accomplish this, the government established the Securities and Exchange Board of India (SEBI), modeled closely after the US Securities Exchange Commission. Following the establishment of SEBI, a number of significant capital market reforms were put in place: new regulations strengthening corporate disclosure and governance standards, new regulations and enforcement mechanisms to ensure orderly and fair trading practices on the country's stock exchanges, and opening the market to international financial intermediaries. Companies were allowed to float shares at market prices, rather than at the artificially low prices dictated by the Controller of Capital Issues. Finally, Indian companies were also allowed for the first time to list on international stock exchanges. All these changes resulted in significantly improved financial markets in India, and enhanced the ability of entrepreneurs and established businesses to access domestic and international equity capital.

These changes, coupled with a significant deregulation of product markets, led to new opportunities and challenges for business groups. A number of first generation entrepreneurs were able to tap into the capital markets to exploit new business opportunities. Prominent among them was the Reliance Group, which raised vast sums of money on the Bombay Stock Exchange to finance its petrochemical ventures to become one of the largest enterprises in India. Reliance went on to become a diversified business group when it began to exploit new business opportunities thrown open with the deregulation of power and telecommunication sectors. This era also gave rise to a number prominent companies in the software and pharmaceutical sectors - Infosys, Wipro, and Satyam Computer Services in software, and Ranbaxy and Dr. Reddy's in pharmaceuticals. Some these companies are family controlled but professionally 
managed (Wipro, Satyam, Ranbaxy, and Dr. Reddy's); some are diversified (Wipro operating in consumer products and information technology) while others are focused in one sector (Infosys, Satyam, Ranbaxy, and Dr. Reddy's).

While the development of capital markets and the deregulation and globalization of the Indian economy has given rise to the birth of these new entrepreneurial firms, some of the old family business groups also have adapted and grown during this era. The most prominent among them is the Tata group which continues to be the largest business group in India. The Tata group has been able to exploit many of the new business opportunities in software and telecom. Today, TCS, one of the Tata group companies, is the country's largest information technology services company, and Tata Telecom is one of the largest telecommunication companies in India.

\section{The Indian Software Industry}

\section{(a) Why study the software industry?}

The software services industry provides a lower bound on the relative advantage of family business groups over independent entrepreneurs in exploiting new opportunities for a number of reasons. First, the industry was very conducive to de novo entry because of low capital requirements, little government regulation on entry, and a relatively low level of minimum economic scale to achieve profitability. Further, the Indian government invested in elite technical institutions, such as the Indian Institutes of Technology and Indian Institutes of Management, and a large number of other engineering colleges. These institutions produced abundant talent, a critical input for the software services industry. Graduates of these institutions, relying on a recognized education brand, were more willing to work for de novo startups than for incumbent business groups. Finally, government policies restricting operations of multinationals such as IBM left plenty of opportunities for domestic entrepreneurs. Given all these factors, software services is one industry where individual entrepreneurs could compete effectively with established family business houses of India. Further, business houses could not rely on any ability they might have had to exercise regulatory muscle, since there were no regulations to muscle into. Thus, the history of software industry, and the 
role of business groups in this industry, provide further evidence on why business groups play such an important role in India even today.

\section{(b) Origins of the Indian Software Industry}

Until the mid-1960s, there was virtually no software development going in India. Whatever software sold was bundled with computers sold by multinational companies like IBM. The early software development efforts focused on producing in-house applications for efficient use of these computers. Government policies attempted to encourage the growth of a domestic hardware industry through high import tariffs on hardware. State owned hardware companies, such as the Electronic Corporation of India Limited, attempted to produce computers for domestic academic and commercial use, and these efforts included development of operating systems, compilers and application packages. Most of these efforts, however, were not very successful.

Of course, many of the reasons to which modern observers attribute the success of today's Indian software industry - e.g. low cost talent, English language, and a tradition of entrepreneurship - did in fact exist prior to the 1960s. The fact that the industry did not, however, and the fact that the industry continues not to have made a mark in other low-cost, English speaking countries suggests that these are certainly not sufficient conditions for the success of the Indian software industry.

It is instructive that the industry really got its start with the establishment in 1968 of Tata Consultancy Services (TCS), a wholly-owned subsidiary of Tata Sons, itself the holding company of the Tata Group, a diversified business group and the epitome of concentrated ownership. As per Heeks (1996), TCS was the first commercial organization to subscribe to the export-commitment related terms under which the Indian government allowed the import of hardware. Tata's ostensible purpose was to allow its diverse companies to use computers in their operations. Toward this end, the company formed an alliance with Burroughs Corporation. Under this alliance, Burroughs would help secure US clients for TCS; in return, TCS would act as an exclusive sales agent for Burroughs hardware in India. Based on this alliance, TCS secured its first U.S. client the Detroit Police Department. TCS today is the largest software services company in 
India employing more than 19,000 software engineers. The company is privately held, fully owned by Tata Sons Limited, the apex of the Tata group companies.

But it was a serendipitous event that triggered the rise of TCS, having to do with the withdrawal of the 'incumbent,' IBM, in 1978. IBM took this step in response to the Foreign Exchange Regulation Act (FERA) of India, which limited multinational companies (MNCs) to a maximum of $40 \%$ ownership stake in their Indian subsidiaries, and specified policies for access to foreign exchange for imports, and the use of foreign exchange earned through exports. MNCs had to either choose between reducing their stake to this level by selling their shares to the Indian public, or leave the country. Several MNCs chose to dilute their stakes through public offerings on the Bombay stock exchange, but IBM and Coca Cola were two prominent exceptions. The decision of IBM to leave India meant that 1200 employees of the company had to look for other alternatives to exploit their skills. Many of these employees set up small software consulting companies which would offer software development and maintenance services to former IBM customers, leading to the beginnings of the Indian software industry. The departure of IBM also allowed many smaller hardware companies to expand into India, exposing Indian software programmers to a variety of software platforms.

Other unintended consequences of Indian government policy also played a role in shaping the nascent industry. For example, the severe import restrictions on hardware requirements of government permits, high customs duties, and control of foreign currency availability - gave a fillip to the industry practice that received the derogatory title of 'bodyshopping,' whereby programmers were shipped off to the client site and worked on the client's computers. This in turn led to some companies building relationships with their clients that were then to play a major role in shaping the industry.

The outward-looking nature of the industry from the outset was also influenced by the unattractiveness of the domestic market. This, in turn, had several causes. First, fearing unemployment from automation, the government did not encourage the adoption of computerization in government and state-owned enterprises. Second, its interest in developing a domestic hardware industry led the government to impose extremely high tariffs (350 percent in much of the 1970s and early 1980s). Third, Indian private sector companies had little incentive to adopt information technology to improve operations and 
productivity, given the highly protected nature of the economy. As a result, Indian software firms found it difficult to generate much demand for their services in the domestic market. This outward orientation stood in significant contrast to the orientation of much of the Indian private sector, which was focused on the Indian domestic market rather than the export market.

More broadly than these specific serendipitous events, software slipped under the discerning bureaucrat's otherwise omnipresent proverbial radar screen, so to speak. The origin of India's socialist policies and heavy-handed micromanagement of enterprise lay in Oxford \& Cambridge-indoctrinated Fabian socialism which sought to regulate the 'commanding heights' of the economy. But this required physical assets to control. Software, with its characteristic intangibles, was too ephemeral to be included in the purview of these regulations.

Other than the intangible nature of the assets in question in the software industry, another reason why the industry escaped some of the pernicious effects of Indian socialism had to do with its non-capital-intensive nature. The state's stranglehold on the financial sector did not matter as much. Several of the last decade's changes have helped move an already existing industry along. For example, far-ranging deregulation initiated following an exchange-rate crisis in 1990 generically improved the outlook for business. The delicensing of hardware imports and the greatly falling hardware prices internationally meant that entry barriers into the Indian domestic software industry fell drastically. Software firms were allowed to set up private telecommunications networks to promote remote software services (often to clients in the west). The party in power until early 2004, the Bhartiya Janata Party (BJP), was generally pro-business and the first to explicitly support the software industry in its election manifesto.

But our general point is that these recent changes do not shed much light on the origins of the industry. It is interesting to ask how a low-cost, talent-intensive environment could become a world-player in a knowledge-intensive industry. Clearly serendipity, as opposed to explicit design, played a role. More interestingly for our purposes, concentrated ownership, in the garb of TCS, was the best positioned to capitalize on the opportunities revealed by serendipity. Indeed, the ownership links among the Tata companies were among the ties that cemented them (along with director 
interlocks, a shared if informal access to the Tata brand, and shared senior level talent), and permitted TCS to leverage the Tata Group's reputation. It is doubtful that an entity could have arisen in a vacuum, unaffiliated with an existing reputable private sector entity, to capitalize on the software industry opportunity. In a subsequent sub-section, we will show how TCS's approach differed from that of other firms in India and that, not only did TCS not deter the entry of de novo aspirants, it actually facilitated entry.

\section{(c) The modern industrial organization of the Indian software industry}

Table 7 shows the distribution of the companies in the industry by revenues. Table 8 shows a list of top 20 companies and their revenues. The top five firms in the industry, with sales greater than 10 billion Indian rupees, account for 32 percent of the total revenues of the industry. These five firms are: Tata Consultancy Services (TCS), Infosys Technologies, Wipro Technologies, Satyam Computer Services, and HCL Technologies. TCS, Wipro, and Satyam are affiliated with family owned business groups, which entered the software industry as part of a diversification move by their parent groups. TCS is privately owned; Wipro is publicly traded, but approximately 84 percent of the shares are held by the founder; Satyam is publicly traded, with only 11 percent of the shares held by the founding family. Infosys and HCL were started by computer professionals, and are publicly listed companies. There are also several large Indian software companies that are affiliates of multinational companies. These include Indian arms of overseas software services firms such as IBM Global Services. Also, there are arms of multinational operating companies which use India as a base for their internal software development needs. Examples include Siemens Information Systems Limited and Motorola. Affiliates of multinational companies together account for 22 percent of the industry's total revenues. There are 24 large software companies that are publicly traded on the Indian stock exchanges. ${ }^{8}$ Three of these - Infosys, Satyam, and Wipro- are also listed on the U.S. stock exchanges.

Compare the industrial organization of the software industry to that of the Indian economy as a whole reported in Tables $2 \& 3$. The role of the private sector looms much

\footnotetext{
${ }^{8}$ There were also other software companies that are publicly listed, but these have very small amount of sales.
} 
larger than that of the (absent) public sector in the software industry than it does in the economy at large. There are large, dominant software firms that have emerged separating the wheat from the chaff, as it were - and this has happened through the normal forces of global competition. Three of the five most successful companies in the software industry - TCS, Wipro, and Satyam - were launched by business groups, and remain affiliated to these groups ${ }^{9}$. Whereas absence of capital barriers to entry characterizes the industry, reputation, the forte of those groups that have succeeded, poses a formidable barrier to entry. Further, from the fact that multinationals have not been able to displace the domestic group companies, we can conjecture that the reputation of the former is probably based at least in part on some hard-to-replicate ability to run a software company in India.

\section{(d) The Success of the Indian Software Industry}

The case of the Indian software industry provides a contrasting picture to the received wisdom that primarily emphasizes the ills of concentrated ownership. ${ }^{10}$ Here, we provide some broad data to support the claim that the software industry is, in fact, a success story despite the ubiquity of concentrated ownership. Why do we think of this as a success? In contrast to the lackluster performance of the Indian economy as a whole, the performance of the Indian software industry has been impressive. ${ }^{11} 12$ The industry's

\footnotetext{
${ }^{9}$ A fourth company, Infosys, has a very high level of insider ownership even though it is not affiliated with a business group.

${ }^{10}$ Morck, Shleifer and Vishny (1988) used U.S. data to argue that the monitoring benefits of concentrated ownership declined beyond a certain threshold level of concentrated ownership. A more recent literature on corporate governance around the world points to the exploitation of minority shareholders by controlling concentrated owners as being a prevalent problem (La Porta et al. 2000; Shleifer \& Wolfenzon, 2002). Morck et al. 1998 have argued that concentrated ownership has resulted in the onset of 'Canadian disease' which they associate with slower growth, lower innovation and other forms of non-competitive malaise. ${ }^{11}$ This history relies on the following sources: Delong and Nanda (2002), Heeks (1996), Ghemawat (2002), NASSCOM (2002, 2003), Kennedy (2001), and Kummerle (2003).

${ }^{12}$ Some aggregate performance indices for the country are worth keeping in mind to interpret the software industry numbers. At the macro level, India's overall economic performance during the post-independence years can only be characterized as relatively poor. For example, the United Nation's Human Development Report of 2002 ranks India 124 among the 173 countries. According to the statistics reported by the Planning Commission of the Government of India, the country's GNP grew at annual average rate of approximately 4 percent between 1951 and 1990. This rate increased to approximately 6 percent in the post-reform years of 1990 to 2002. India's population has grown significantly to 1.05 billion by 2002 . While government spending on public education was more around 3 percent of GNP, a disproportionate amount of this went to supporting higher education. According to the Indian government's 2001 Census of India, adult illiteracy rate stood at 34.6 percent in 2001. Agriculture still remained the dominant source of
} 
total revenues in 2002 stood at $\$ 10.2$ billion, and it grew at more than $40 \%$ per year during the 1990s. The industry accounted for $\$ 7.7$ billion in exports in 2002 , which was a significant portion of the approximately $\$ 73.3$ billion total exports of goods and services from India in that year. ${ }^{13}$ One indication of technical prowess is that five of the nine software development centers in the world with CMM Level 5 ratings, the highest ratings on the predominant quality scale developed for software at Carnegie-Mellon University, were located in India. Companies like General Electric, Citicorp and IBM had their only CMM-certified operations in India rather than in the U.S. ${ }^{14}$ According to a report prepared by the international consulting firm McKinsey for the National Association of Software and Service Companies (NASSCOM), an industry trade association, the industry is expected to grow to $\$ 77$ billion by 2008 , accounting for 7 percent of India's GDP, 33 percent of its foreign exchange inflows, and 4 million jobs. By all these measures, software industry is the crown jewel of India's post-independence economy.

While this establishes that the Indian software industry has done well relative to any sensible domestic benchmark, two other benchmarks are worth considering. Consider, first, comparisons with U.S. software companies, and then, comparisons of the Indian industry with itself, as it were, over time.

Table 9 compares the largest Indian software companies with the some of the largest U.S. software companies in terms of revenues, employees, profitability, and market capitalization, all as of 2002. Indian companies are clearly not as large as some of the largest US software firms such as CSC, Accenture, and EDS in terms of revenues or manpoer. However, in terms of profitability, Indian firms are significantly better than

income for a very significant portion of the population, and there were significant levels of unemployment and underemployment. Per capita GNP in 2001 stood at approximately $\$ 450$ dollars. A caveat to this interpretation is that, in the two decades leading to 2000, India's cumulative average growth rate was second only to China's in this time period. Our reading is that it was a good performance, but not stellar enough to alleviate the suffering of the Indian masses. In a recent analysis, De Long (2001) argues that India was in the middle of the pack of countries that he analyzes over longer time periods.

${ }^{14}$ It may be that quality concerns are greater when a firm is located in an environment with a reputation for poor governance and poor quality products. Perhaps U.S. firms do not find it necessary to seek certification of this sort. 
their US counterparts. The stock market valuations of Indian companies, despite their smaller size, are often larger than the market capital of the US firms. ${ }^{15}$

Consider, now, the industry's evolution over time. Table 10 shows the time-series of the total activity of the Indian software industry from 1988 to 2002. The industry had a total revenue of 0.7 billion Indian rupees in 1988, and the proportion of exports to domestic sales was 41 percent. By 2002, the industry grew to a size of 365 billion rupees, with exports accounting for 76 percent. This is driven by the rising importance of offshore services (from 51\% of export revenues in 2002 from 5\% in 1991), the valueadded part of the Indian software firms' offerings. This, in turn, is a reflection of gradually developed reputations for reliability and high quality of services, starting from a base of primarily bodyshopping (Banerjee and Duflo, 2000). By 2000, the U.S. accounted for $66 \%$ of the total exports of the industry and UK accounted for the second largest share of exports, at 14\%. 185 of the Fortune 500 US companies were customers of the Indian software services industry.

This smorgasbord of data leaves us relatively convinced that, despite the ubiquity of concentrated ownership, it is hard to tell a story of a sclerotic industry, engulfed with rent-seeking behavior and in its death throes. Quite the contrary. It is also instructive to note that direct measures of corporate governance, which we turn to below, also do not yield predictions consistent with the predicted dismal effects of concentrated ownership.

The Indian software industry, on average, appears to follow better corporate governance practices relative to the rest of the Indian industry, consistent with the hypothesis that globalization puts pressure on companies to improve their governance to global standards. Some data from Credit Lyonnais Securities Analysis (CLSA, 2001) supports this assessment of the current state of Indian corporate governance. The data are from a set of questions regarding corporate governance administered to 482 companies in 24 emerging markets in 2001. The companies are generally the ones of greater interest to foreign investors, typically characterized by some subset of the following characteristics - large size, greater equity float, and foreign listings. When we ranked countries by the mean corporate governance score constructed by CLSA, we found that India ranked in

\footnotetext{
${ }^{15}$ Software industry market capitalization on Indian stock exchanges rose from $\$ 4$ bn in January 1999 to a high of $\$ 90$ bn and then, following the NASDAQ crash and its ripple effect in India, settled at $\$ 55$ bn by mid-2000.
} 
about the middle. Since most countries in these data have poor average corporate governance (with some exceptions like Hong Kong and Singapore), and since the selected companies are generally the better governed ones, this confirms the characterization offered above.

The same CLSA data, however, also point out that the corporate governance ratings of the software firms are higher than those of other Indian firms. The mean ratings for software firms (of which there are eight in the CLSA data) and for non-software firms (of which there are 72) are, respectively, 64.3 and 54.7 (minimum of 0 and maximum of 100 ), with the difference statistically significantly with a p-value of 0.02 . The medians are, similarly, 62.9 and 53.8, with the difference statistically significant with a p-value of 0.2 .

The data also confirm that software firms are, on average, more exposed to global competition than other Indian firms. To ratify this assertion, we supplemented CLSA data with a variety of indicators of global competition. Software firms are more likely to be traded on a U.S. stock exchange ( $p$ value 0.02) and on the London Stock Exchange ( $p$ value 0.08 ) and more likely to be listed on the NYSE (p value 0.01 ). Software firms garner a higher percentage of their revenues through exports ( $p$ value 0.01 ), are more likely to employ foreign talent in senior managerial positions ( $\mathrm{p}$ value 0.01 ) and are somewhat more likely to employ a Big 5 accounting firm (p value 0.12 ). ${ }^{16}$

Finally, having established that the Indian software industry outperforms domestic benchmarks (in terms of profitability, market capitalization, and corporate governance), outperforms U.S. benchmarks, and is improving over time, consider some evidence that, while least precise, is perhaps farthest reaching. The social transformation brought about by the rise of the software industry is difficult to exaggerate. Most compellingly, Indian talent have role models of entrepreneurship - from both de novo bootstrapped firms and from business group offshoots - to spur them forward (Khanna and Palepu, 2004). Individuals, in rural and urban settings, are much closer to having the information they need to be 'empowered' (Das, 2000). Indeed, rural India is being transformed by the roadside availability of computing power (in much the same way that a previous

\footnotetext{
${ }^{16}$ However there is no statistically significant difference between software and non-software firms in the proportion of equity held by institutional investors.
} 
dissemination of franchised telephone kiosk services around the country revolutionized telecommunication service provision). It is thus difficult to escape the conclusion that the positive spillovers from the Indian software industry exceed, perhaps vastly, the direct benefits internalized by stakeholders of the industry.

\section{(e) A Tale of Two Software Firms}

In this section, we provide a more detailed description of two very successful firms in the Indian software industry, TCS affiliated with the Tata group, and Infosys, a new entrepreneurial venture arising out of the opportunities provided by the new economic environment. Elsewhere, we have argued that there are two qualitatively different 'solutions' to the instutitional voids that hamper entrepreneurship in emerging markets. The first is for incumbent groups to leverage their internal access to capital and talent to start new ventures - this is the TCS story - and the second is for aspirants to tap into external institutions outside the country - this is the Infosys story (Khanna and Palepu, 2004).

The stories of these two firms shows how group affiliated firms coexist successfully with independent entrepreneurial firms in this industry. It also demonstrates that the success of group affiliated firms is attributable not to their ability to exploit government connections, but due to their ability to exploit entrepreneurial opportunities in the economy successfully. Finally, not only is it not the case that the group, the embodiment of concentrated ownership, deterred the entry of the unaffiliated firm, it actually laid the groundwork for a vast array of subsequent entrants.

The founding of Tata Consultancy Services (TCS) in 1968 marks the birth of the first Indian domestic software firm at a time when IBM was riding herd in India. ${ }^{17}$ TCS was set up by India's oldest business group, the House of Tata, by pooling together management talent from existing Tata companies to create a new entity to act as an information technology bureau for various members of the Tata group. In two senses, it is the prototypical example of the filling of institutional voids (Khanna and Palepu, 1997, $1999,2000 \mathrm{a}, \mathrm{b}$ ), that is, of the creation by diversified business groups of internal solutions

\footnotetext{
${ }^{17}$ The data, though not the interpretation, for the few paragraphs on the founding of TCS are from Kennedy (2001).
} 
to compensate for the absence of external specialized intermediaries (institutional voids). The voids in question here refer to the absence of intermediaries facilitating the pooling of talent to launch such a company and the absence of an entity to provide information technology services to service the corporate demands of the time.

Armed with the reputation of the Tata Group, and its track record in India, TCS sought business overseas, turning successfully to secure an alliance with Burroughs Corporation in the U.S., whereby Burroughs would secure programming contacts and TCS would execute them. Under newly appointed CEO F. C. Kohli, TCS built up a credible list of major Indian customers between 1969 and $1973 .^{18}$

It is important to realize that India's distortionary foreign exchange regulations played a key role in prompting TCS to solicit business overseas. Foreign exchange was needed to pay for importing the hardware on which TCS performed its software programming services. It is also worth noting that such cross-border arrangements have been common in the history of the Tata group. For example, its ventures in the late 1990s included joint venture agreements with the likes of AT\&T, NTT, Honeywell, Jardine Matheson, (the then) Daimler Benz, and numerous others. Elsewhere we have argued that the network of joint venture agreements represent credible commitments not to engage in short-term opportunistic behavior toward the marginal joint venture partner, and that the network itself is facilitated by the diverse (cross-industry) scope of the Tata Group (Khanna and Palepu 1997).

Experience gained domestically and through Burroughs meant that TCS was wellpositioned when another distortionary Indian regulation - the requirement of divesting sufficient equity to local partners - forced IBM (and several other multinationals) out of India in 1977. A separate entity - Tata Burroughs (later Tata Infotech) - was created to focus on business based on the Burroughs platform, while TCS decided to focus on the rising IBM platform in its outside-India work. A U.S. office was opened in 1979 to solicit business and, with successful projects for various banks, American Express, IBM and others under its proverbial belt, TCS had established the industry, and its position, by the mid 1980s.

\footnotetext{
${ }^{18}$ It is true that the MIT-trained Kohli's own contacts in the U.S., as part of the IEEE association, no doubt played a facilitating role in securing contacts. But of course Tata's had the reputation to attract someone of Kohli's stature in the first instance.
} 
In contrast to TCS, Infosys Technologies, another of India's software success stories, is the prototypical example of building a business by leveraging external (i.e. non-India specific) institutions to compensate for domestic (India-specific) institutional voids. Narayan Murthy, the individual most associated with Infosys today, mused that the biggest challenge facing Infosys was "running a first-world firm in a third world country' (Nanda and De Long, 2002, page 9). Infosys was founded in 1981 by seven entrepreneurs, all ex-employees of Patni Computer Systems (itself one of the entrants into the post-IBM-withdrawal vacuum). Its initial capital consisted of approximately $\$ 1,000$ of personal savings and no Tata-like reputation to leverage. However, at least one of the founders, Murthy, had his professional outlook sensitized to the importance of personal incentives by his own stint working outside India (Paris).

Infosys struggled, teetering on the precipice of bankruptcy in 1989, until a foreign exchange crisis forces India to 'open up.' Reasons cited for Infosys' early difficulties can reasonably be traced to pre-1991 institutional voids in product markets (lack of availability of quality hardware), capital markets (limited availability of financing for de novo entrepreneurs) and labor markets (visa restrictions preventing cross-border talent mobility). A lot of these constraints were removed when barriers to the flow of people, capital and ideas were relaxed so that Indosys software engineers could be relocated relatively easily to their customer sites, Infosys management did not spend excessive time circumventing regulations in New Delhi, foreign knowhow regarding the industry was accessible, and equity capital could be accessed locally through listings (which Infosys did in 1993).

While the post-1991 liberalization eliminated some institutional voids, more fundamental ones remained. A Forbes article commented that there was a "perception that a smart, honest, reputable company could never come out of a country where cows still run in the street. ${ }^{, 19}$ A 1999 NASDAQ listing was designed to ameliorate informational problems that hampered Infosys reaching blue-chip companies in the global market. Several executives at Infosys and its competitors, and several regulators at Securities and Exchange Board of India (SEBI; India's SEC equivalent) commented to us, for example,

\footnotetext{
${ }^{19}$ Eric Pfeiffer, 'From India to America,' Forbes ASAP, August 23, 1999, pp. 19-24. Quoted in De Long and Nanda (2002: pp. 13).
} 
that the NASDAQ listing was designed primarily to gain credibility with customers and to permit the issuance of dollar-denominated stock options to compete in global markets for talent. ${ }^{20}$ For a company that, by this time, was not liquidity constrained, as we have demonstrated elsewhere (Khanna and Palepu, 2004), raising capital was not the reason to list overseas. SEBI member Jayanth Verma's comment to us regarding the spate of software listings overseas that followed is instructive. "The industry that probably needs capital the least, went after the international capital markets most aggressively.... In fact many of these companies don't know what to do with the capital they raised. .. The pressures that the capital markets can put on a company that doesn't need to raise capital are next to nothing."

A few final points are worth noting. First, TCS's moves arguably laid the foundation for the industry's development. Azim Premji, founder of Wipro, India's second largest software company and an NYSE-listed company, commented, 'The legacy of the early pioneers - Tata Consultancy Services - was a growing number of foreign companies favorably impressed about what Indian companies could do in software' (Ramamurti, 2001). Thus, TCS, launched by the Tata group, far from deterring entry, appears to have facilitated it.

\section{Discussion: The (socially useful) persistence of concentrated ownership}

In this section, we argue that the persistence of concentrated ownership is, in fact, a robust feature of many, if not most, emerging markets. The story of the Indian software industry, and the (socially) useful role that business groups with concentrated ownership play in it, is not an artifact of serendipitous outcomes, but has generalizable aspects to it. In contrast, the literature's current focus on the dark side of concentrated ownership, to the virtually complete exclusion of the positive aspects, has the potential to understate the beneficial aspects of such ownership, especially in emerging markets.

\footnotetext{
${ }^{20}$ Note, however, that the international listing was not feasible until Infosys had a stable track record. As Azim Premji, CEO of rival Wipro commented, 'It is also important to remember that Indian companies built their expertise serving domestic customers before venturing abroad' (Ramamurti, 2001). Even TCS ventured overseas after it had a strong domestic track record.
} 
Consider other instances in space and time that are consistent with this idea of the socially productive longevity of concentrated ownership. We have focused on Chile in earlier work on the sustainability of business groups (Khanna and Palepu, 2000b) because Chile is the one country in modern economic history that has arguably undergone one of the most rapid movements toward a market economy, starting from the socialist society left behind by Salvador Allende in 1973 (following his overthrow by the right-wing General Augosto Pinochet). In particular, Chilean markets are widely celebrated as being the best in Latin America especially since 1990. Thus, if one were to see business groups atrophy as external markets develop, this is where one ought to find the effect most glaringly. Our study confirmed that the value of business group affiliation fell during the ten years between 1987 and 1997. But business group affiliation, even in the relatively developed markets of the late 1990s, continued to be valuable. Our interpretation was that group capabilities, under attack in this instance since 1973 and especially since 1990, fall slowly.

We supplemented this by detailed fieldwork in nine of Chile's largest groups over the same time period (Khanna and Palepu, 1999). It is important to note that these were not the ten best performing groups. Here we found that these groups bucked the trend, so to speak, by not only improving their performance over this time period, but by increasing the trend toward greater concentration in ownership, greater family control and greater diversfication, all allegedly correlates of the deleterious effects of concentrated ownership. Similar field evidence was obtained and reported from India in the 1990-1997 time period.

The parallels with business groups in history are uncanny and relatively unexplored (Jones and Khanna, 2003). Here we draw largely on the work on multinational trading companies in the 1800s and 1900s by Geoffrey Jones (2000). Primarily around the mid 1800s, British trading houses in particular (and trading houses originating elsewhere in Europe to a lesser extent) were cross-border structural analogs of the sorts of contemporary business groups that one observes in Chile, India and elsewhere (Khanna, 2000). In these trading companies, which Jones describes as business groups, the merchant house was the 'core' and was tied through a medley of contracts, informal 
and formal, to a series of separately publicly quoted (traded) affiliates around the world, which operated in very diverse industries.

Examples of such British trading companies included the Inchcape/Mackinnon group, a shipping enterprise spread over Asia and Australia, with a trading business in the Gulf, India and Africa, and plantations in India. Another was Jardine Matheson, which originated as an opium trader between China and India and, drawing extensively on its Scottish heritage to source talent, evolved into a multinational business group with operations in China, and outposts in Japan, the U.S., South Africa and Peru, in diverse services and manufacturing businesses and an active venture capital business in mining worldwide.

Some funds were draw from British (and other) expatriate savings in the colonies and from the London capital markets, and a lot of funds were sourced locally. That is, there was the structural issue of controlling and minority shareholders that we have already discussed as a hallmark of contemporary groups. Yet, as Jones points out, while the potential for minority shareholder exploitation existed in spades, there were very few such cases. Why? His answer is that reputation mattered, and these business groups sought to build trust by doing things like foregoing commissions (owed to the core firm by the affiliates as compensation for management services rendered) when times were bad. The groups referred to a 'moral responsibility' toward their affiliates. Thus we have an instance where concentrated ownership appears to have exercised self-restraint, even amidst a weak corporate control environment, a factor that was probably associated with its longevity.

Consider also the adaptability of this historical business group, another reason why the concentrated ownership has persisted. Continuing the examples above, the Inchcape group gradually divested from India in the late 1960s and 1970s as that country became less attractive, and also withdrew from the Middle East and Africa, ultimately reconfiguring itself as a group invested in Southeast Asia, Hong Kong and Australia. Jardines and Swires recovered from rather drastic business setbacks, including the Communist revolution in China, and reconfigured themselves as Hong Kong based groups, and entered numerous new businesses. Such reconfigurations can be observed even in contemporary groups. The Tata group started, for example, with a steel and 
airlines and insurance in the $1800 \mathrm{~s}$, had to undergo nationalization and confiscation of several of its major businesses (including airlines and insurance), built up and eventually divested major businesses in consumer products, and most recently, entered, successfully, automobiles, and software. Thus, TCS, discussed above, is a recent diversification of the Tata group. Similarly, the roughly $\$ 4$ bn Ayala Group in the Philippines started with distilleries and has evolved into a real estate and financial services group as of the 1990s, and most recently as a major and very successful player in mobile telephony (Khanna, Palepu, and Vargas, 2004).

Groups, and the concentrated ownership that they represent, whether in history or in contemporary emerging markets, are robust forms of business organizations. They potentially last centuries, changing their footprint and functional form, and weathering severe shocks. Whereas egregious violations and crony capitalism by groups are often reported (e.g. Fisman's 2001 study of groups in Suharto's Indonesia), the constructive stories are actually far more numerous, even though lacking the drama of exploitation.

As a coda, it is worth commenting on the implicit counterfactual that underpins our assertion that groups are socially productive organizational forms. One should ask, what would happen if there were no groups? Would organized commerce happen in quite the way that it does in emerging markets, when the specialized intermediation needed to facilitate arms-length transactions between buyers and sellers in all manner of markets are missing? We think not. Such a world would be closer to first-best, but is also patently unrealistic. Then, a critic of groups might say, groups are sensible responses to the absence of specialized intermediation at a point in time, but their very presence deters the emergence of intermediaries. Therefore groups are self-perpetuating. There is some truth to this (Khanna, 2000), but it is a characterization that rings more true for extreme concentration of groups as in South Korea or South Africa, than for the 'median' emerging market. 


\section{Bibliography}

Arora, Ashish and Athreye, Suma, 2002. The software industry and India's development. Information Economics and Policy, 14, pp. 253-273.

Athreye, Suma S. 2002. The Indian software industry and its evolving service capability. Open University Working Paper, UK.

Banerjee, Abhijit V. and Esther Duflo. 2000. Reputation Effects and the Limits of Contracting: A Study of the Indian Software Industry. The Quarterly Journal of Economics, (August): 989-1017.

Bertrand, Marianne, Mehta, Paras, and Mullainathan, Sendhil, 2002. Ferreting out tunneling: An application to Indian Business Groups, Quarterly Journal of Economics, Vol. 117, No. 1, pp. 121-148.

Bhagwati, Jagdish (1993): India in Transition: Freeing the Economy, Clarendon Press, Oxford.

CLSA. 2001. Saints \& Sinners: Who's Got Religion? Credit Lyonnais Securities Asia, Research Report. Hong Kong.

Das, Gurcharan. 2000. India Unbound: From Independence to the Global Information Age, Penguin Books.

De Long, J. Bradford, 2001. India since independence: An analytic growth narrative, UC Berkeley Department of Economics Working Paper, July.

DeLong, Thomas and Nanda, Ashish. 2002. Infosys Technologies. HBS Case No. 801445 Boston: Harvard Business School Publishing.

Dutt Report 1969. Report of the industrial licensing policy enquiry committee, Main Report. Government of India.

Ferguson, Niall. 2002. Empire: The Rise and Demise of the British World Order and the Lessons for Global Power, Allen Lane, Penguin Books, London, England.

Fisman, Raymond, 2001. Estimating the value of political connections, American Economic Review. September Vol. 91, Iss. 4; p. 1095

Gadgil, D. R. 1951. (with Staff of Gokhale Institute of Politics and Economics, Poona, India). Notes on the Rise of the Business Communities in India. Mimeograph, International Secretariat, Institute of Pacific Relations, New York, NY, April.

Ghemawat, Pankaj. 1999. The Indian Software Industry in 2002. HBS Case No. 700-036 Boston: Harvard Business School Publishing. 
Ghemawat, Pankaj and Khanna, Tarun. 1998. "The Nature of Diversified Business Groups: A Research Design and Two Case Studies," Journal of Industrial Economics, Volume XLVI, No. 1, pp. 35-62, March.

Greif, A. 1994. Cultural beliefs and the organization of society: A historical and theoretical reflection on collectivist and individualist societies. Journal of Political Economy, 102 (5), 912-950

Hazari, R. K. 1966. The structure of the corporate private sector: A study of concentration, ownership and control, Bombay: Asia Publishing House.

Hazari, R. K. 1986. Industrial Policy in Perspective. in Essays on Industrial Policy. New Delhi: Naurang Rai Concept Publishing Company.

Heeks, Richard. 1996. India's Software Industry: State Policy, Liberalisation and Industrial Development. New Delhi: Sage Publications.

Jones, G. 2000. Merchants to Multinationals. Oxford: Oxford University Press, 2000.

Jones, G., and Tarun Khanna, 2003. Bringing History into International Business, Harvard Business School unpublished mimeograph.

Kennedy, Robert E. 2001. Tata Consultancy Services: High Technology in a LowIncome Country. HBS Case No. 9-700-092. Harvard Business School Publishing.

Kapur, Devesh, and Ravi Ramamurti. 2001. India's Emerging Competitiveness in Tradable Services. Academy of Management Executive, vol. 15, no. 2 (May).

Khanna, Tarun. 1997. Modern India. HBS Case No. 797-108 (Boston: Harvard Business School Publishing.

Khanna, Tarun, 2000. Business groups and social welfare in emerging markets: Existing evidence and unanswered questions European Economic Review. Amsterdam: May Vol. 44, Iss. 4-6; p. 748

Khanna, Tarun, Krishna Palepu, Why focused strategies may be wrong for emerging markets, Harvard Business Review. Boston: Jul/Aug 1997. Vol. 75, Iss. 4; p. 41 (8 pages)

Khanna, T., and Palepu, Krishna. 1999. Policy Shocks, Market Intermediaries, and Corporate Strategy: Evidence from Chile and India. Journal of Economics and Management Strategy 8, no. 2,. 271-310. June.

Khanna, Tarun, Krishna Palepu, 2000a Is group affiliation profitable in emerging markets? An analysis of diversified Indian business groups, The Journal of Finance. Cambridge: Apr 2000. Vol. 55, Iss. 2; p. 867 
Khanna, Tarun, Krishna Palepu, 2000b. The future of business groups in emerging markets: Long-run evidence from Chile, Academy of Management Journal. Briarcliff Manor: June. Vol. 43, Iss. 3; p. 268

Khanna, Tarun and Krishna Palepu, 2000c. Emerging Market Business Groups, Foreign Intermediaries, and Corporate Governance, in Concentrated Corporate Ownership, edited by Randall Morck (Chicago and London: The University of Chicago Press, 2000.

Khanna, Tarun and Palepu, Krishna, 2004. Globalization and Convergence in Corporate Governance: Evidence from Infosys and the Indian Software Industry, forthcoming, Journal of International Business Studies.

Khanna, Tarun and Palepu, Krishna, and Wu, Danielle Melito, 1998. House of Tata 1995-The Next Generation (A). HBS Case No. 798-037, Boston: Harvard Business School Publishing.

Khanna, Tarun, Palepu, Krishna, and Vargas, Ingrid, 2004. Globe Telecom. HBS Case No. 704-505, Boston: Harvard Business School Press.

Kuemmerle, Walter. 2003. Infosys: Financing an Indian Software Start-Up. HBS Case No. 800-103, Boston: Harvard Business School Publishing.

Lamb, Helen B. 1976. Studies on India and Vietnam. New York: Monthly Review Press.

La Porta, Rafael, Florencio Lopez-de-Silanes, Andrei Shleifer, Robert Vishny, 2000.

Investor protection and corporate governance, Journal of Financial

Economics. Amsterdam: Oct/Nov. Vol. 58, Iss. 1,2; pg. 3

Leff, N. 1976. Capital markets in the less developed countries: The group principal. In R. McKinnon (Ed.), Money and Finance in Economic Growth and Development. New York: Marcel Dekker.

Leff, N. 1978. Industrial organization and entrepreneurship in the developing countries: The economic groups. Economic Development and Cultural Change, 26: 661-75.

Morck, Randall, David A. Stangeland, Bernard Yeung, 1998. Inherited Wealth, Corporate Control and Economic Growth: The Canadian Disease, NBER Working Paper November

Morck, Randall, Shleifer, Andrei, Vishny, Robert W., Management Ownership and Market Valuation: An Empirical Analysis, 1988. Journal of Financial Economics. Amsterdam: Jan/Mar. Vol. 20, Iss. 1,2; pg. 293, 23 pgs

NASSCOM 2002. National Association of Software and Service Companies. NASSCOM-McKinsey Report 2002: Strategies to achieve Indian IT industry's aspiration. New Delhi, India: National Association of Software and Service Companies, June. 
NASSCOM 2003. National Association of Software and Service Companies. Strategic Review: The IT Industry in India, New Delhi, India: National Association of Software and Service Companies, February

Piramal, Gita, 1989. Long Shadows of the Past. Corporate Dossier, The Economic Times, India, August 18, 1989.

Piramal, Gita, 1991. The Politics of Business, Perspectives- The Independent Journal of Politics and Business, India, March 28.

Piramal, Gita, 1998. Business Legends. Viking Penguin India. New Delhi.

Shleifer, Andrei, Daniel Wolfenzon, 2002. Investor protection and equity markets Journal of Financial Economics. Amsterdam: Oct. Vol. 66, Iss. 1; p. 3

Strachan, H. 1976. Family and other business groups in economic development: The case of Nicaragua. NY: Praeger.

Swamy, Subramanian. 1979. The response to economic challenge: A comparative economic history of China and India: 1870-1952. Quarterly Journal of Economics.

Ramamurti, Ravi, 2001. Wipro's CEO Azim Premji on building a world-class Indian company, Academy of Management Executive, Vol. 15, No. 2, May.

Timberg, Tom. 1978. The Marwaris. New Delhi, Vikas. 
Table 1

Origin of Concentrated Ownership over the Years

\begin{tabular}{|c|c|c|c|c|}
\hline & 1900s & 1950s & 1960s & 1990s \\
\hline Period & $\begin{array}{c}\text { Pre- } \\
\text { Independence }\end{array}$ & $\begin{array}{c}\text { Post } \\
\text { Independence }\end{array}$ & License Raj & Liberalization \\
\hline $\begin{array}{c}\text { Representative } \\
\text { Business } \\
\text { Group }\end{array}$ & Tata, Birla & Goenka, Khaitan & Ambani & $\begin{array}{l}\text { Wipro/Infosys } \\
\text { Ranbaxy/DRL }\end{array}$ \\
\hline $\begin{array}{c}\text { Factor } \\
\text { underlying } \\
\text { rise }\end{array}$ & $\begin{array}{c}\text { Ethnic } \\
\text { Community }\end{array}$ & $\begin{array}{l}\text { Transfer of } \\
\text { Assets }\end{array}$ & $\begin{array}{l}\text { Playing the } \\
\text { license game }\end{array}$ & $\begin{array}{l}\text { Advent of } \\
\text { markets }\end{array}$ \\
\hline
\end{tabular}


Table 2

Comparison of Indian Public Sector, Private Sector, and Multinational Corps., 1993

\begin{tabular}{lll}
\hline $\begin{array}{l}\text { Expressed } \\
\text { in ratio }\end{array}$ & $\begin{array}{l}\text { Private sector compared } \\
\text { to public sector }\end{array}$ & $\begin{array}{l}\text { Indian private sector } \\
\text { compared to all foreign }^{\mathbf{a}}\end{array}$ \\
\hline \#ompanies
\end{tabular}

Source: Author's calculations from a datebase maintained by the Center for Monitoring the Indian Economy (CMIE), Bombay, India. Found in Tarun Khanna, "Modern India," HBS Case No. 979-108 (Boston: Harvard Business School Publishing, 1997, p. 7.

${ }^{a}$ The private sector is comprised of Indian group-affiliated firms (IG) and Indian non-group affiliated firms (IN). The public sector is comprised of central and state government owned firms (P). This column depicts, for each category, the ratio $(\mathrm{IG}+\mathrm{IN}) / \mathrm{P}$. (i.e. there are 16.92 times as many companies in the private sector as there are in the public sector, but total sector sales are only 1.53 times greater than total public sector sales.)

${ }^{\mathrm{b}}$ This column depicts the Indian private sector relative to foreign firms (F), i.e., the ratio: (IG+IN)/ F. 
Table 3

Comparison of Group and Non-Group Firms Listed on the Bombay Stock Exchange in 1993.

\begin{tabular}{|c|c|c|c|c|}
\hline & Group & Firms & Nongroup & Firms \\
\hline Variables & Mean & Median & Mean & Median \\
\hline $\begin{array}{l}\text { Sales (million of } \\
\text { rupees) }\end{array}$ & 1,411 & 666 & 366 & 217 \\
\hline Age (years) & 28.3 & 22 & 19.8 & 14 \\
\hline Tobin's $q$ & 1.39 & 1.14 & 1.37 & 1.06 \\
\hline $\begin{array}{l}\text { Ownership by foreign } \\
\text { institutional investors } \\
(\%)\end{array}$ & 10.1 & 2.3 & 7.4 & 0.9 \\
\hline $\begin{array}{l}\text { Ownership by Indian } \\
\text { institutional investors } \\
(\%)\end{array}$ & 15.6 & 13.3 & 11.3 & 6.5 \\
\hline $\begin{array}{l}\text { Ownership by insiders } \\
(\%)\end{array}$ & 31.9 & 31.3 & 20.8 & 17.1 \\
\hline $\begin{array}{l}\text { Directors'ownership } \\
(\%)\end{array}$ & 5.7 & 1.1 & 14.2 & 10.7 \\
\hline $\begin{array}{l}\text { Top fifty owners } \\
\text { excluding the above } \\
\text { categories }(\%)\end{array}$ & 4.9 & 3.2 & 7.6 & 5 \\
\hline Number of firms & 567 & 567 & 437 & 437 \\
\hline
\end{tabular}

Source: Tarun Khanna and Krishna Palepu, "Emerging Market Business Groups, Foreign Intermediaries, and Corporate Governance," in Concentrated Corporate Ownership, ed. Randall K. Morck (Chicago: The University of Chicago Press, 2000), P. 276. Data obtained from the Center for Monitoring the Indian Economy (CMIE) for 567 affiliates of 252 different groups and for 437 unaffiliated firms traded on the BSE.

Note: The summary statistics in this table are based on 1993 values. Tobin's $q$ is defined as (market value of equity + book value of preferred stock + book value of debt)/(book value of assets). Sales are measured in millions of rupees, with an approximate exchange rate at this time of U.S. $\$ 1.00=$ Rs 30.00. Age measures number of years since incorporation. Foreign institutional ownership aggregates ownership of foreign corporations as well as that of foreign financial intermediaries. Domestic institutional ownership aggregates ownership in the hands of all state-run financial intermediaries. Insider ownership includes the stakes held by group family members and by other group firms and measures stakes held by insiders for nongroup firms. Directors' ownership captures the ownership of nonfamily directors. Top fifty ownership captures the largets shareholders not included in the aforementioned categories. Group membership is based on definitions of groups from CMIE (see text of paper for comments). The mean and median values for all the variables except for the mean value of Tobin's $q$ and change in Tobin's $q$ are significantly different between the group and nongroup firms at the 5 percent significance level. 
Table 4

Top 50 Indian Business Groups down the Years**

Courtesy Dr Gita Piramal

\begin{tabular}{|c|c|c|c|c|c|c|}
\hline & \multicolumn{2}{|c|}{ 1939* } & \multicolumn{2}{|c|}{$1969^{\circ}$} & \multicolumn{2}{|l|}{$1997 \#$} \\
\hline & Group & Asset & Group & Assets & Group & Assets \\
\hline 1 & Tata & 62.42 & Tata & 505.36 & Tata & $\begin{array}{l}37510.8 \\
0\end{array}$ \\
\hline 2 & Martin Burn & 18.02 & Birla & 456.40 & BK-KM Birla & $\begin{array}{l}19497.9 \\
4\end{array}$ \\
\hline 3 & Bird & 12.40 & Martin Burn & 153.06 & Reliance & $\begin{array}{l}19345.5 \\
9\end{array}$ \\
\hline 4 & Andrew Yule & 12.38 & Bangur & 104.31 & RPG & 9664.12 \\
\hline 5 & Inchcape & 10.70 & Thapar & 98.80 & Essar & 9593.78 \\
\hline 6 & E D Sassoon & 9.56 & S Nagarmull & 95.61 & OP Jindal & 5456.10 \\
\hline 7 & $\mathrm{ACC}$ & 8.68 & Mafatlal & 92.70 & MAC & 4782.10 \\
\hline 8 & Begg & 5.75 & $\mathrm{ACC}$ & 89.80 & LM Thapar & 4434.09 \\
\hline 9 & $\begin{array}{l}\text { Oriental } \\
\text { Tel\&Elec }\end{array}$ & 5.60 & Walchand & 81.11 & Ispat & 4425.35 \\
\hline 10 & Dalmia & 5.51 & Shriram & 74.13 & Group USHA & 4210.87 \\
\hline 11 & Jardine & 5.33 & Bird Heilgers & 68.62 & Lalbhai & 4112.44 \\
\hline 12 & Wallace Bros & 5.33 & JK Singhania & 66.84 & Videocon & 3737.87 \\
\hline 13 & Birla & 4.85 & Goenka & 65.34 & Lloyd Steel & 3705.27 \\
\hline 14 & Wadia & 4.70 & Sahu Jain & 58.75 & Bajaj Group & 3415.87 \\
\hline 15 & Duncan & 4.54 & $\begin{array}{l}\text { Macneill \& } \\
\text { Barry }\end{array}$ & 57.28 & $\begin{array}{l}\text { Williamson } \\
\text { Magor }\end{array}$ & 3351.62 \\
\hline 16 & Finlay & 3.84 & Sarabhai & 56.72 & Hari S Singhania & 3275.80 \\
\hline 17 & Scindia & 3.66 & Scindia & 55.99 & KK Birla & 3094.90 \\
\hline 18 & Killick & 3.51 & Lalbhai & 51.20 & Torrent & 3077.23 \\
\hline 19 & Kilburn & 3.23 & Killick & 51.08 & Hinduja & 2967.20 \\
\hline 20 & Sarabhai & 3.00 & ICI & 50.06 & Arvind Mafatlal & 2862.94 \\
\hline 21 & Brady & 2.82 & Andrew Yule & 46.75 & $\begin{array}{l}\text { Murugappa } \\
\text { Chettiar }\end{array}$ & 2840.62 \\
\hline 22 & $\begin{array}{l}\text { Rajputana } \\
\text { Textiles }\end{array}$ & 2.80 & TVS & 43.83 & Escorts & 2642.22 \\
\hline
\end{tabular}




\begin{tabular}{|c|c|c|c|c|c|c|}
\hline & \multicolumn{2}{|l|}{ 1939* } & \multicolumn{2}{|c|}{$1969^{\circ}$} & \multicolumn{2}{|c|}{$1997 \#$} \\
\hline & Group & $\begin{array}{c}\text { Asset } \\
\text { s }\end{array}$ & Group & Assets & Group & Assets \\
\hline 23 & Steel Bros & 2.77 & Kirloskar & 43.02 & Mahindra & 2633.70 \\
\hline 24 & MacLeod & 2.67 & Parry & 41.93 & GP Goenka & 2630.43 \\
\hline 25 & Walchand & 2.61 & Jardine Hend. & 40.19 & CK Birla & 2530.32 \\
\hline 26 & Lawrie & 2.55 & Mahindra & 38.58 & Kirloskar & 2622.61 \\
\hline 27 & Thackersey & 2.56 & Bajaj & 35.28 & Nagarjuna & 2511.54 \\
\hline 28 & Mafatlal & 2.45 & Simpson & 32.92 & $\begin{array}{l}\text { Jaiprakash } \\
\text { Group }\end{array}$ & 2442.48 \\
\hline 29 & BIC & 2.38 & Seshasayee & 32.72 & Indo Rama & 2440.88 \\
\hline 30 & Lalbhai & 2.33 & $\begin{array}{l}\text { Gill } \\
\text { Arbuthnot }\end{array}$ & 29.02 & UB Group & 2414.65 \\
\hline 31 & Kettlewell & 2.23 & Kilachand & 27.22 & Kalyani & 2395.29 \\
\hline 32 & Gillanders & 2.16 & Dalmia J & 26.72 & GE Shipping & 2357.59 \\
\hline 33 & Shri Ram & 2.16 & Naidu GV & 26.41 & Oswal Agro & 2342.36 \\
\hline 34 & Swedish Match & 2.05 & $\begin{array}{l}\text { Shapoor } \\
\text { Pallonji }\end{array}$ & 26.36 & Wadia & 2334.97 \\
\hline 35 & $\begin{array}{l}\text { Octavious } \\
\text { Steel }\end{array}$ & 2.00 & $\begin{array}{l}\text { Turner } \\
\text { Morrison }\end{array}$ & 23.15 & Manu Chhabria & 2286.02 \\
\hline 36 & Shaw & 1.95 & Ruia & 22.40 & TS Santhanam & 2214.06 \\
\hline 37 & CV Mehta & 1.90 & Naidu VR & 21.55 & SK Birla & 2080.11 \\
\hline 38 & Mangaldas & 1.80 & A\&F Harvey & 21.33 & $\begin{array}{l}\text { Vijaypat } \\
\text { Singhania }\end{array}$ & 1979.88 \\
\hline 39 & Daga & 1.67 & Wadia & 20.56 & Modern & 1967.85 \\
\hline 40 & Forbes & 1.59 & Shaw Wallace & 20.14 & MM Thapar & 1963.47 \\
\hline 41 & Harvey & 1.50 & Murugappa & 20.07 & Ranbaxy & 1875.71 \\
\hline 42 & Dunlop & 1.42 & Modi & 19.38 & $\begin{array}{l}\text { SRF/A Bharat } \\
\text { Ram }\end{array}$ & 1863.26 \\
\hline 43 & Spencer & 1.38 & RamaKrishna & 18.79 & Finolex & 1712.73 \\
\hline
\end{tabular}




\begin{tabular}{|l|l|l|l|l|l|c|}
\hline & \multicolumn{2}{|c|}{$1939^{*}$} & \multicolumn{2}{c|}{$1969^{\circ}$} & \multicolumn{2}{c|}{$1997 \#$} \\
\hline & \multicolumn{1}{|c|}{ Group } & $\begin{array}{c}\text { Asset } \\
\mathrm{s}\end{array}$ & \multicolumn{1}{c|}{ Group } & \multicolumn{1}{c|}{ Assets } & \multicolumn{1}{c|}{ Group } & Assets \\
\hline 44 & Williamson & 1.23 & Chinai & 18.36 & Godrej & 1695.97 \\
\hline 45 & Harrisons & 0.89 & Jaipuria & 18.24 & BPL & 1691.57 \\
\hline 46 & Henderson & 0.63 & Kamani & 18.05 & Vinod Doshi & 1519.89 \\
\hline 47 & C Jehangir & 0.42 & Rallis & 17.94 & Usha Martin & 1514.06 \\
\hline 48 & Turner & 0.39 & Thackersey & 17.19 & OWM & 1412.76 \\
\hline 49 & Provident & 0.34 & Thiagaraja & 16.55 & Amalgamation & 1353.47 \\
\hline 50 & J Warren & 0.22 & $\begin{array}{l}\text { Swedish } \\
\text { Match }\end{array}$ & 15.70 & Vardhman & 1282.40 \\
\hline
\end{tabular}

Source:

* compiled from Claude Markovits, Indian Business \& Nationalist Politics. P192-3. Significant exclusions (for a miscellaneous bunch of reasons) from the list are: BAT, Thomas Duff, J Taylor, Assam Company, Burmah Oil, F Peek and Hukumchand. As we are concerned only with Indian groups and as rankings are not relevant for the purpose of this article, we can safely assume that all the key Indian business houses have been accounted for the pre-independence period in the table.

${ }^{\circ}$ compiled from Report of the Industrial Licensing Policy Inquiry Committee, 1969.

\# Business Today.

$\sim$ Ruia in 1969 list should not be confused with Essar Ruia of the 1997 list.

** Assets in RsCr. Normally sales or market cap are the accepted international criteria for ranking business performance. However assets have been taken in this case for the sake of uniformity. Accurate, reliable and complete data for Indian business houses by sales is not available pre-1984. 
Table 5

Top U.S. Firms down the Years

\begin{tabular}{|c|c|c|c|}
\hline RANKING & $\begin{array}{l}\text { COMPANY } \\
\text { NAME } 1939\end{array}$ & $\begin{array}{l}\text { COMPANY } \\
\text { NAME 1969 }\end{array}$ & $\begin{array}{l}\text { COMPANY } \\
\text { NAME } 1999 \\
\end{array}$ \\
\hline 1 & $\begin{array}{c}\text { American } \\
\text { Telephone \& Teleg } \\
\text { Co }\end{array}$ & $\begin{array}{l}\text { International } \\
\text { Business Machs Cor }\end{array}$ & Microsoft Corp \\
\hline 2 & $\begin{array}{l}\text { General Motors } \\
\text { Corp }\end{array}$ & $\begin{array}{l}\text { American } \\
\text { Telephone \& Teleg } \\
\text { Co }\end{array}$ & General Electric Co \\
\hline 3 & $\begin{array}{l}\text { Du Pont E I De } \\
\text { Nemours \& Co }\end{array}$ & $\begin{array}{l}\text { General Motors } \\
\text { Corp }\end{array}$ & Cisco Systems Inc \\
\hline 4 & Standard Oil Co NJ & Eastman Kodak Co & Wal Mart Stores Inc \\
\hline 5 & General Electric Co & Standard Oil Co NJ & Exxon Mobil Corp \\
\hline 6 & $\begin{array}{l}\text { Union Carbide \& } \\
\text { Carbon Corp }\end{array}$ & $\begin{array}{l}\text { Sears Roebuck \& } \\
\text { Co }\end{array}$ & Intel Corp \\
\hline 7 & $\begin{array}{l}\text { United States Steel } \\
\text { Corp }\end{array}$ & Texaco Inc & $\begin{array}{l}\text { Lucent } \\
\text { Technologies Inc }\end{array}$ \\
\hline 8 & $\begin{array}{c}\text { International Nickel } \\
\text { Co CDA Ltd }\end{array}$ & Xerox Corp & $\begin{array}{l}\text { International } \\
\text { Business Machs Cor }\end{array}$ \\
\hline 9 & Texas Co & General Electric Co & Citigroup Inc \\
\hline 10 & $\begin{array}{c}\text { Sears Roebuck \& } \\
\text { Co }\end{array}$ & Gulf Oil Corp & America Online Inc \\
\hline 11 & Coca Cola Co & $\begin{array}{l}\text { Minnesota Mining } \\
\& \text { Mfg Co }\end{array}$ & $\begin{array}{l}\text { American } \\
\text { International Group } \\
\text { Inc }\end{array}$ \\
\hline 12 & Kress SH \& Co & $\begin{array}{l}\text { Du Pont E I De } \\
\text { Nemours \& Co }\end{array}$ & $\begin{array}{l}\text { SBC } \\
\text { Communications } \\
\text { Inc }\end{array}$ \\
\hline 13 & $\begin{array}{l}\text { Allied Chemical \& } \\
\text { Dye Corp }\end{array}$ & Avon Products Inc & AT\&T Corp \\
\hline 14 & $\begin{array}{l}\text { Procter \& Gamble } \\
\text { Co }\end{array}$ & Coca Cola Co & Oracle Corp \\
\hline 15 & Eastman Kodak Co & Mobil Oil Corp & Home Depot Inc \\
\hline 16 & $\begin{array}{l}\text { Kennecott Copper } \\
\text { Corp }\end{array}$ & $\begin{array}{l}\text { Procter \& Gamble } \\
\text { Co }\end{array}$ & Merck \& Co Inc \\
\hline 17 & $\begin{array}{c}\text { Standard Oil Co } \\
\text { IND }\end{array}$ & $\begin{array}{l}\text { Standard Oil Co } \\
\text { California }\end{array}$ & MCI WorldCom Inc \\
\hline 18 & Chrysler Corp & Polaroid Corp & $\begin{array}{l}\text { Procter \& Gamble } \\
\text { Co }\end{array}$ \\
\hline 19 & $\begin{array}{l}\text { Socony Vacuum Oil } \\
\text { Inc }\end{array}$ & Merck \& Co Inc & Coca Cola Co \\
\hline 20 & Woolworth FW Co & $\begin{array}{l}\text { Atlantic Richfield } \\
\text { Co }\end{array}$ & $\begin{array}{l}\text { Nortel Networks } \\
\text { Corp }\end{array}$ \\
\hline 21 & Reynolds RJ & American Home & Dell Computer Corp \\
\hline
\end{tabular}




\begin{tabular}{|c|c|c|c|}
\hline & Tobacco Co & Products Corp & \\
\hline 22 & $\begin{array}{c}\text { Consolidated Edison } \\
\text { Co NY Inc }\end{array}$ & $\begin{array}{l}\text { International Tel \& } \\
\text { Teleg Corp }\end{array}$ & Johnson \& Johnson \\
\hline 23 & $\begin{array}{l}\text { Commonwealth } \\
\text { Edison Co }\end{array}$ & $\begin{array}{l}\text { Standard Oil Co } \\
\text { IND }\end{array}$ & $\begin{array}{l}\text { Bristol Myers } \\
\text { Squibb Co }\end{array}$ \\
\hline 24 & United Gas Impt Co & Johnson \& Johnson & Pfizer Inc \\
\hline 25 & $\begin{array}{c}\text { Standard Oil Co } \\
\text { California }\end{array}$ & $\begin{array}{l}\text { International Nickel } \\
\text { Co CDA Ltd }\end{array}$ & $\begin{array}{l}\text { Sun Microsystems } \\
\text { Inc }\end{array}$ \\
\hline 26 & $\begin{array}{l}\text { Chesapeake \& Ohio } \\
\text { Railway Co }\end{array}$ & $\begin{array}{l}\text { General Tel \& } \\
\text { Electrs Corp }\end{array}$ & QualComm Inc \\
\hline 27 & $\begin{array}{c}\text { Pennsylvania } \\
\text { Railroad Co }\end{array}$ & Shell Oil Co & Hewlett Packard Co \\
\hline 28 & $\begin{array}{l}\text { Norfolk \& Western } \\
\text { Railway Co }\end{array}$ & Ford Motor Co Del & Yahoo Inc \\
\hline 29 & $\begin{array}{c}\text { Westinghouse } \\
\text { Electric \& Mfg Co }\end{array}$ & Burroughs Corp & EMC Corp MA \\
\hline 30 & $\begin{array}{l}\text { Montgomery Ward } \\
\& \mathrm{Co}\end{array}$ & Penney JC Inc & Bell Atlantic Corp \\
\hline 31 & American Can Co & $\begin{array}{l}\text { Pacific Telephone \& } \\
\text { Teleg Co }\end{array}$ & Motorola Inc \\
\hline 32 & $\begin{array}{l}\text { International } \\
\text { Harvester Co } \\
\end{array}$ & $\begin{array}{l}\text { Caterpillar Tractor } \\
\text { Inc }\end{array}$ & BellSouth Corp \\
\hline 33 & $\begin{array}{l}\text { Bethlehem Steel } \\
\text { Corp }\end{array}$ & Weyerhaeuser Co & $\begin{array}{l}\text { Bank of America } \\
\text { Corp }\end{array}$ \\
\hline 34 & $\begin{array}{c}\text { Anaconda Copper } \\
\text { Mng Co }\end{array}$ & $\begin{array}{l}\text { Westinghouse } \\
\text { Electric Corp }\end{array}$ & Time Warner Inc \\
\hline 35 & American Tob Co & $\begin{array}{l}\text { Georgia Pacific } \\
\text { Corp }\end{array}$ & $\begin{array}{l}\text { Morgan Stanley } \\
\text { Dean Witter and Co }\end{array}$ \\
\hline 36 & General Foods Corp & Union Carbide Corp & $\begin{array}{l}\text { Daimlerchrysler AG } \\
\text { Stuttgart }\end{array}$ \\
\hline 37 & $\begin{array}{c}\text { Roan Antelope } \\
\text { Copper Mines Ltd }\end{array}$ & $\begin{array}{l}\text { Goodyear Tire \& } \\
\text { Rubr Co }\end{array}$ & $\begin{array}{l}\text { Texas Instruments } \\
\text { Inc }\end{array}$ \\
\hline 38 & United Fruit Co & $\begin{array}{l}\text { Pfizer Chas \& Co } \\
\text { Inc }\end{array}$ & $\begin{array}{l}\text { Berkshire Hathaway } \\
\text { Inc Del }\end{array}$ \\
\hline 39 & Penney JC Inc & Bristol Myers Co & $\begin{array}{l}\text { American Express } \\
\text { Co }\end{array}$ \\
\hline 40 & $\begin{array}{c}\text { Pacific Telephone \& } \\
\text { Teleg Co }\end{array}$ & Honeywell Inc & BP Amoco PLC \\
\hline 41 & $\begin{array}{c}\text { Liggett \& Myers } \\
\text { Tob Co }\end{array}$ & RCA Corp & Lilly Eli \& Co \\
\hline 42 & Parke Davis \& Co & $\begin{array}{l}\text { Warner Lambert } \\
\text { Pharmaceutical Co }\end{array}$ & Warner Lambert Co \\
\hline 43 & $\begin{array}{c}\text { Pacific Gas \& Elec } \\
\text { Co }\end{array}$ & Dow Chemical Co & $\begin{array}{l}\text { Du Pont E I De } \\
\text { Nemours \& Co }\end{array}$ \\
\hline 44 & $\begin{array}{l}\text { Union Pacific } \\
\text { Railroad Co }\end{array}$ & General Foods Corp & GTE Corp \\
\hline
\end{tabular}




\begin{tabular}{|c|c|c|c|}
\hline 45 & Phelps Dodge Corp & Imperial Oil Ltd & Wells Fargo \& Co \\
\hline 46 & North American Co & $\begin{array}{l}\text { Creole Petroleum } \\
\text { Corp }\end{array}$ & $\begin{array}{l}\text { Tyco International } \\
\text { Ltd New }\end{array}$ \\
\hline 47 & $\begin{array}{l}\text { Phillips Petroleum } \\
\text { Co }\end{array}$ & $\begin{array}{l}\text { Pacific Gas \& Elec } \\
\text { Co }\end{array}$ & AT\&T Corp \\
\hline 48 & $\begin{array}{c}\text { Commercial } \\
\text { Investment Trust Co }\end{array}$ & Kresge SS Co & $\begin{array}{l}\text { Chase Manhattan } \\
\text { Corp New }\end{array}$ \\
\hline 49 & Public Svc Corp & $\begin{array}{l}\text { Reynolds RJ } \\
\text { Tobacco Co }\end{array}$ & $\begin{array}{l}\text { Federal National } \\
\text { Mortgage Assn }\end{array}$ \\
\hline 50 & $\begin{array}{c}\text { Wrigley William Jr } \\
\text { Co }\end{array}$ & $\begin{array}{l}\text { United States Steel } \\
\text { Corp }\end{array}$ & $\begin{array}{l}\text { Schering Plough } \\
\text { Corp }\end{array}$ \\
\hline
\end{tabular}

Source: Compustat, based on market values. 


\section{Table 6}

Persistence of Dominance of Indian Groups and U.S. firms over 60 Years

\begin{tabular}{|l|l|l|l|l|}
\hline & Indian Groups & Indian Groups & U.S. Firms & U.S. Firms \\
& $1939-1969$ & $1969-1999$ & $1939-1969$ & $1969-1999$ \\
\hline Birth & 32 & 43 & 28 & 37 \\
\hline RankUp & 6 & 3 & 7 & 5 \\
\hline RankDown & 10 & 3 & 15 & 6 \\
\hline RankUp10 & 5 & 2 & 1 & 2 \\
\hline RankDown10 & 5 & 1 & 4 & 3 \\
\hline RankSame & 2 & 1 & 0 & 2 \\
\hline
\end{tabular}

Birth refers to the number of groups or firms that are 'born' in the 30-year window in question, that is, that enter the top 50 list for that country in that time window, given that they were not part of the list in the previous 30 year window (there are no groups or firms that exit and then re-enter the top 50 list in either country). RankUp refers to the number of groups or firms that rise in the asset-based size rankings. A smaller rank measures a larger group or firm, with rank $=1$ and rank $=50$ being the largest and the smallest of the top-50 groups or firms in each country in each time period. RankUp10 counts the groups or firms whose rank rises by more than 10. RankDown and RankDown10 are defined analogously. RankSame counts the number of groups or firms whose rank remains unchanged during that 30 year period. 
Table 7

Structure of Indian Software Exports Industry

No. of Companies

\begin{tabular}{lll}
\hline Annual turnover & $\mathbf{2 0 0 0 - 0 1}$ & $\mathbf{2 0 0 1 - 0 2}$ \\
\hline Above Rs. 1,000 crore & 5 & 5 \\
\hline Rs. 500 crore - Rs. 1,000 crore & 7 & 5 \\
\hline Rs. 250 crore - Rs. 500 crore & 14 & 15 \\
\hline Rs. 100 crore - Rs. 250 crore & 28 & 27 \\
\hline Rs. 50 crore - Rs. 100 crore & 25 & 55 \\
\hline Rs. 10 crore - Rs. 50 crore & 193 & 220 \\
\hline Below Rx. 10 crore & 544 & 2,483 \\
\hline
\end{tabular}

Note: In 2001-02, companies under Rs. 10 crore revenues included non-NASSCOM member companies.

Source: Adapted from "NASSCOM: Strategic Review 2003: The IT Industry in India" ( New Delhi, 2003). Available from the National Association of Software and Service Companies. 


\section{Table 8}

\section{Top 20 IT Software and Services Exporters from India}

\begin{tabular}{llll}
\hline Rank & Company & Rs. core & US\$ million \\
\hline $\mathbf{1}$ & Tata Consultancy Services & 3,882 & 813 \\
\hline $\mathbf{2}$ & Infosys Technologies Limited & 2,553 & 535 \\
\hline $\mathbf{3}$ & Wipro Technologies & 2,256 & 481 \\
\hline $\mathbf{4}$ & Satyam Computer Services Limited & 1,703 & 357 \\
\hline $\mathbf{5}$ & HCL Technologies. Ltd. & 1,319 & 277 \\
\hline $\mathbf{6}$ & IBM Global Services India Pvt. Ltd. & 764 & 160 \\
\hline $\mathbf{8}$ & Patni Computer Services & 732 & 153 \\
\hline $\mathbf{9}$ & Silverline Technologies & 603 & 126 \\
\hline $\mathbf{1 0}$ & Mahindra-British Telecom Limited & 541 & 113 \\
\hline $\mathbf{1 1}$ & Pentasoft Technologies Ltd. & 459 & 96 \\
\hline $\mathbf{1 2}$ & HCL Perot Systems Ltd. & 449 & 94 \\
\hline $\mathbf{1 3}$ & Pentamedia Graphics Ltd. & 431 & 90 \\
\hline $\mathbf{1 4}$ & NIIT Limited & 400 & 84 \\
\hline $\mathbf{1 5}$ & Mascot Systems Ltd. & 399 & 84 \\
\hline $\mathbf{1 6}$ & i-Flex Solutions Ltd. & 392 & 82 \\
\hline $\mathbf{1 7}$ & Digital Globalsoft Ltd. & 331 & 69 \\
\hline $\mathbf{1 8}$ & Mphasis BFL Group (Consolidated) & 313 & 66 \\
\hline $\mathbf{1 9}$ & Mascon Global Limited & 307 & 64 \\
\hline $\mathbf{2 0}$ & Orbitech & 264 & 55 \\
\hline $\mathbf{S 0}$ & Mastek Limited & 259 & 54 \\
\hline
\end{tabular}

Source: Adapted from "NASSCOM: Strategic Review 2003: The IT Industry in India" ( New Delhi, 2003). Available from the National Association of Software and Service Companies. 
Table 9

A Comparison of the large US and Indian Software Companies

\begin{tabular}{|c|c|c|c|c|}
\hline & $\begin{array}{l}\text { Revenues } \\
\text { June 2002, } \\
\text { \$ million ttm }\end{array}$ & $\begin{array}{l}\text { Operating } \\
\text { Margin } \\
\text { June 2002, } \\
\text { Per cent ttm }\end{array}$ & $\begin{array}{l}\text { No. of } \\
\text { Employees } \\
\text { June 2002 }\end{array}$ & $\begin{array}{l}\text { Market } \\
\text { Capitalization } \\
\text { October 2002, } \\
\text { \$ million }\end{array}$ \\
\hline \multicolumn{5}{|l|}{$\begin{array}{l}\text { U.S. } \\
\text { Companies }\end{array}$} \\
\hline Accenture & 11,600 & 3.9 & 75,000 & 12,400 \\
\hline CSC & 11,500 & 4.7 & 67,000 & 4,800 \\
\hline EDS & 22,300 & 10.3 & 143,000 & 6,370 \\
\hline \multicolumn{5}{|l|}{ KPMG } \\
\hline Consulting & 2,368 & 5.6 & 9,300 & 1,240 \\
\hline Sapient & 217 & N/A & 2,427 & 123 \\
\hline \multicolumn{5}{|l|}{$\begin{array}{l}\text { Indian } \\
\text { Companies }\end{array}$} \\
\hline HCL Tech & 340 & 28.1 & 5,587 & 1,209 \\
\hline Infosys & 571 & 32.1 & 10,470 & 7,140 \\
\hline Satyam & 421 & 26.7 & 9,532 & 1,370 \\
\hline TCS & 810 & 25 & 19,000 & 8,100 \\
\hline Wipro & 734 & 24.5 & 13,800 & 6,340 \\
\hline
\end{tabular}

Source: Adapted from "NASSCOM Newsline, November 2002" (2002). Available from the National Association of Software and Service Companies. $<\mathrm{http}: / /$ www.nasscom.org $>$ 
Table 10

India's Software Exports, Domestic Sales, and Imports (Rs. Billion/\$ Million)

\begin{tabular}{|c|c|c|c|c|}
\hline Year & $\begin{array}{l}\text { Exports } \\
\text { Rs. }\end{array}$ & US\$ & $\begin{array}{l}\text { Domestic } \\
\text { Sales }\end{array}$ & $\begin{array}{l}\text { Exports/ } \\
\text { Total Sales (\%) }\end{array}$ \\
\hline $1987-88$ & Rs. 0.70 & $\$ 52$ & Rs. 1.00 & 41 \\
\hline $1990-91$ & Rs. 2.50 & $\$ 128$ & Rs. 2.25 & 52 \\
\hline 1991-1992 & Rs. 4.30 & $\$ 164$ & Rs. 3.20 & 57 \\
\hline $1992-93$ & Rs. 6.70 & $\$ 225$ & Rs. 4.90 & 57 \\
\hline 1993-94 & Rs. 10.20 & $\$ 330$ & Rs. 6.95 & 59 \\
\hline 1994-95 & Rs. 15.30 & $\$ 485$ & Rs. 10.70 & 59 \\
\hline $1995-96$ & Rs. 25.20 & $\$ 735$ & Rs. 16.70 & 60 \\
\hline 1996-97 & Rs. 39.00 & $\$ 1,110$ & Rs. 25.00 & 61 \\
\hline $1997-98$ & Rs. 65.30 & $\$ 1,790$ & Rs. 35.80 & 64 \\
\hline 1998-99 & Rs. 109.00 & $\$ 2,650$ & Rs. 49.50 & 68 \\
\hline 1999-00 & Rs. 171.50 & $\$ 4,000$ & Rs. 94.10 & 70 \\
\hline $2000-01$ & Rs. 283.50 & $\$ 6,230$ & Rs. 98.90 & 74 \\
\hline 2001-02 & Rs. 365.00 & $\$ 7,680$ & Rs. 115.00 & 76 \\
\hline
\end{tabular}

Note: The figures for the domestic software activity do not include in-house development of software by end users, which is presumed to be a considerable amount.

Source: Adapted from Pankaj Ghemawat, "The Indian Software Industry in 2002," HBS Case No. 700-036 (Boston: Harvard Business School Publishing, 2002), p. 20. Data from NASSCOM; Heeks, R. India's Software Industry: State Policy, Liberalisation and Development, (New Delhi: Sage Publications, 1996). 
Figure 1

Evolution of the Tata Group: 1900-2003

\section{Year Entered}

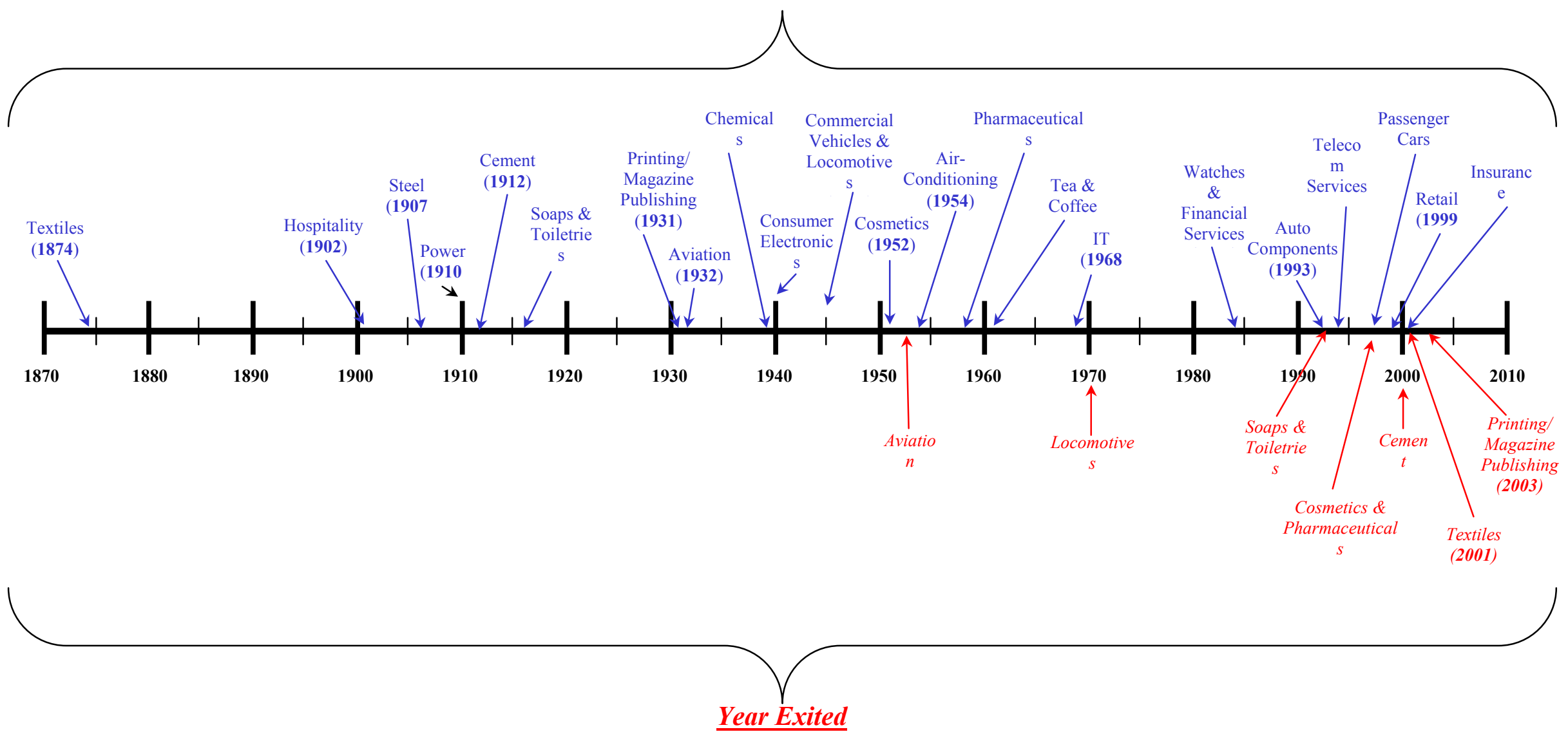

Source: Bombay House, Tata Group, Jan 2004 